\title{
A ACTIO POPULARIS E (N)O DIREITO (PENAL) INTERNACIONAL
}

\section{ACTIO POPULARIS AND INTERNACIONAL CRIMINAL LAW}

\author{
Marcus Vinícius Xavier de Oliveira ${ }^{1}$
}

\begin{abstract}
Resumo
Este trabalho objetivou enfrentar o problema relacionado à vigência, validade e eficácia do instituto da actio popularis no Direito (Penal) Internacional, tendo como ponto de intersecção, de um lado, as decisões proferidas pela Corte Internacional de Justiça nos casos Etiópia e Libéria v. África do Sul nos anos de 1962 e 1966, bem como as críticas efetuadas à virada radical que a Corte promoveu entre os julgamentos das Questões Preliminares e a segunda fase, tendo como substrato teórico a crítica feita por Egon Schwelb. Para tanto, logo após estabelecer as bases da discussão no tema relativo à transição do sistema westfaliano para o da Carta, discorreu-se sobre a origem do instituto no direito romano, tendo como principal apoio a obra de Theodor Mommsen. Ato seguido passou-se à apresentação e discussão das decisões da Corte Internacional de Justiça no caso indicado, para apontar-se, em linhas posteriores, as críticas que referida decisão sofreu. No último tópico se discutiu a correlação entre o instituto da actio popularis com a máxima aut dedere aut judicare, em especial no regime indireto de implementação do Direito Penal Internacional. Conclui-se o trabalho com ligeiras considerações a confirmar a vigência, validade e condições de eficácia e legitimidade da justiça cosmopolita, cuja fundamentação encontra-se na actio popularis. O método de abordagem adotado no presente trabalho foi o crítico, e o de procedimento a consulta bibliográfica.
\end{abstract}

Palavras-chave: Actio Popularis; Aut Dede Aut Judicare; Direito Internacional; Sistemas Internacionais; Direito Penal Internacional; Implementação Indireta

\begin{abstract}
This paper aims to address the problem related to the validity and efficacy of the actio popularis in International (Criminal) Law, having as a point of intersection, on the one hand, the decisions handed down by the International Court of Justice in the cases of Ethiopia and Liberia v. South Africa in the years 1962 and 1966, as well as the criticisms made of the radical turn that the Court promoted between the judgments of the Preliminary Questions and the second phase, having as a theoretical substrate the criticism made by Egon Schwelb. To this end, after establishing the basis of the discussion on the theme related to the transition from the Westphalian system to that of the Charter, the origin of the institute in Roman law was discussed, having as main support the work of Theodor Mommsen. Subsequently, the decisions of the International Court of Justice presented and discussed, in order to point out, in later lines, the criticisms that the decision had suffered. In the last topic, we discussed the correlation between the institute of actio popularis and the maximum aut dedere aut judicare, especially in the indirect system of implementation of International Criminal Law. The work concluded with slight considerations confirming the validity and conditions of efficacy and legitimacy of

\footnotetext{
${ }^{1}$ Professor Adjunto da Universidade Federal de Rondônia. Doutor (UERJ) em Direito. Líder do Jus Gentium - Grupo de Estudos e Pesquisas em Direito Internacional. Membro do Grupo de Pesquisas em Teoria Política Contemporânea. E-mail: marcusoliveira@unir.br
} 
cosmopolitan justice, whose foundation in actio popularis. The method of approach adopted in the present study was the critic, and the procedure was bibliographic.

Keywords: Actio popularis; Aut Dedere Aut Judicare; Contemporary International Law; International Criminal Law; Indirect Enforcement

\section{INTRODUÇÃO}

A discussão acerca da vigência e aplicabilidade do instituto da actio popularis no Direito Internacional contemporâneo, e que se liga diretamente à regra aut dedere aut judiciare, bem como seus significados e efeitos, cuja origem remonta, até onde pudemos aferir, aos casos Etiópia e Libéria v. África do Sul (South-West Africa Cases), julgados pela Corte Internacional de Justiça (doravante CIJ) nos anos de 1962 (primeira fase) e 1966 (segunda fase), constitui-se, conforme se procurará demonstrar nas linhas que seguem, em um tópico privilegiado para se dilucidar as diferenças existentes entre os sistemas internacionais westfaliano ${ }^{2}$ e da $\mathrm{Carta}^{3}$, mormente no que concerne à legitimidade para os Estados atuarem na proteção daquilo que M. Sherif Bassiouni denomina de valores e interesses comuns (common-shared vallues e common-shared interests) da sociedade internacional, com especial ênfase nos campos do Direito Penal Internacional (proscrição e persecução dos autores de crimes internacionais próprios e/ou transnacionais), cuja vinculação, ademais, com o Direito Internacional dos Direitos Humanos é mais do evidente: é de essência ${ }^{4}$.

\footnotetext{
2 Denomina-se Sistema Internacional Westfaliano à ordem internacional surgida no século XVI e que, pondo termo ao sistema internacional do medievo no mesmo passo em que pacificou o continente europeu com o término da Guerra dos Trinta Anos, se fundou sobre os seguintes princípios internacionais, a saber: "1. Os sujeitos do direito internacional estão vinculados às normas do direito internacional consuetudinário que Ihes sejam aplicáveis e pelos princípios gerais do direito reconhecidos pelas nações civilizadas. 2. Podem ser impostas a um sujeito da ordem legal internacional obrigações internacionais adicionais só com o seu consentimento. 3. O exercício da jurisdição internacional é exclusivo para cada Estado, a menos que esteja limitado ou excepcionado por normas do direito internacional. 4. Em certos e especiais casos, os sujeitos do direito internacional podem pretender jurisdição sobre coisas ou pessoas fora de sua jurisdição territorial. 5. A menos que existam regras permissivas, a intervenção de um sujeito de direito internacional na esfera da exclusiva jurisdição doméstica dos outros sujeitos constitui uma ruptura da ordem jurídica internacional" (JOSÉ BREMER, 2013, pp. 66-67).

3 "La Charte des Nations Unies, en second lieu, qui a substitué au "modèle de Wetphalie", caractérisé par la force comme principale source de légitimité, le "modèle de la Charte" (ou "droit des Nations Unies") qui refuse toute légitimité au recours à la force" (WEIL, 1992, p 28).

4 "The identification, application and enforcement of commonly-shared values and commonly-shared interests by the modern international legal system presuppose the existence of a community that postulates certain universal objects and moral imperatives requiring certain actions and compelling the refraining from others. From there we identify the boundaries that limit the actions of states, impel them
} 
O estudo do instituto é importante porque, nada obstante a defesa da tese feita pelos internacional-constitucionalistas segundo de que a sociedade internacional contemporânea já se constitua em uma Comunidade Internacional ${ }^{5}$, parecem-nos mais acertadas as afirmações de Pastor Ridruejo, Thomas Kleinen, Prosper Weil, dentre outros autores, para os quais, de fato, isso ainda não ocorreu. Para aquele primeiro, a característica mais destacada da sociedade internacional contemporânea é a de se encontrar numa fase de transição de uma sociedade de justaposição - modelo westfaliano de Estados independentes -, para uma sociedade de cooperação - modelo da Carta -, em que, ao lado dos interesses particulares dos Estados, passa-se a ter um maior compartilhamento de interesses e valores universais e/ou comuns que devem ser protegidos não pelo Estado, mas pelos Estados a partir de um regime de cooperação que tem na juridicização (Direitos Internacionais Especiais), na institucionalização (constituição de Organizações Internacionais e/ou regimes internacionais) e na jurisdicionalização (sistemas judiciais ou quase-judiciais de soluções de controvérsias) as suas marcas mais significativas (PASTOR RIDRUEJO, 2014, p. 48-49).

Já para Kleinen, o que existe, de fato, é uma Comunidade Internacional em potência, posto que, para sua concretização na facticidade história, deveriam estar presentes os "[...] elementos centrais da dimensão dogmática da teoria da constitucionalização [...]", quais sejam "[...] a hierarquia das normas do direito internacional, o desenvolvimento de uma ordem universal que objetive a proteção dos bens comuns e a vinculação normativa do exercício das competências públicas para além do Estado" (KLEINEN, 2012, p. 315).

Nesse sentido, este estado paradoxal de já, mas ainda não - restando pensar-se, doutro polo, se a efetiva constitucionalização da sociedade internacional é, de fato, factível e desejável (MACEDO, 2016, p. 424) -, tem causado não poucas perplexidades nos estudiosos do Direito Internacional, pelo que muitos têm apelado ao fato de que, com a queda do muro de Berlim em

to cooperate for the common good and act in the common interest. To argue that this is exclusively a moralistic approach is to ignore all that which common experience teaches based on the lessons of justified pragmatic considerations, enlightened self-interest, and prudent judgment. An international community is not therefore dependent on the existence or even the desirability of a world government". (BASSIOUNI, 2006, p. 2).

5 "The international legal order is not the same as it was 66 years ago [...] today a community [...] would seem to come closer [...] to really than any time before [...] States live [...] within a legal framework of a limited number of basic rules which determines their basic rights and obligations with or without their will [...] every State receives its legal entitlement to be respected as a sovereign entity, the constitution of international society [...] community being a term suitable to indicate a closer union than between members of a society [...] Thus, Article 2 (1) of the UN [...] Article 38 of the Statute [...] Article 26 of the Vienna Convention [...] good faith. All of these principles and rules may be relied upon to identify the juridical architecture of the international system [...]" (TOMUSCHAT, 1993, pp. 211-212). 
1989 e os seus desdobramentos posteriores, a sociedade internacional tenha ingressado numa fase de transformações efetivas e concretas rumo à Comunidade Internacional.

Importante, entretanto, repisar as lições de Prosper Weil em seu Cour Général na Haia, em 1992, que se firmando nas lições de Maurice Bourquin de $1931^{6}$, afirma que a ideia de que a queda do muro de Berlim e o fim do império soviético teriam dado novo impulso ao Direito Internacional não passa de um trompe-l'oeil. Em verdade, reportando-se às lições de Gerald Fitzmaurice, o autor alude ao contínuo processo de transformações e mudanças que acompanham o Direito Internacional desde sempre, insistindo, ademais, que apesar da contínua institucionalização da sociedade internacional, os Estado continuam os sujeitos internacionais par excellence (WEIL, 1992, pp. 100-128), mesmo em campos tão prenhes de significados humanitários como o Direito Internacional dos Direitos Humanos.

O mesmo para Malcolm Shaw, para quem, nada obstante o

[...] aumento do número de atores e participantes no sistema jurídico internacional, os Estados permanecem, de longe, como as pessoas coletivas mais importantes e, apesar do aumento da globalização e de tudo o que isso implica, os Estados mantêm a sua atração como o principal foco da atividade social humana e, portanto, do Direito Internacional (SHAW, 2008, p. 197).

Segue na mesma direção Shabtai Rosenne, quando afirma que as transformações pelas quais o Direito Internacional tem passado não thes são nem estranhas nem Ihes retira o seu caráter perene de fator regulante da sociedade internacional conformada, principalmente, mas não exclusivamente, por Estados. Muito pelo contrário, se o Direito Internacional ainda permanece como critério imperioso para as relações entre os Estados, é em razão mesmo dessa sua capacidade de adaptação às constantes mudanças pelas quais tem passado a sociedade internacional, e isso em razão do papel preponderante que o princípio da boa-fé sempre ocupou no âmbito das relações internacionais (ROSENNE, 2004, pp. 449-455).

Assim, o tema abordado no presente trabalho parece se constituir num dos meios pelos quais as conhecidas deficiências do Direito Internacional, sinteticamente alocadas por Pastor

\footnotetext{
6 "C'est devenu une banalité de dire que le droit international est en pleine transformation. Non seulement ses emprises sur la avie des peuples se multiplient, mais le conceptions qui l'inspirent subissent um profond renouvellement... S'il n'y a point, à vrai dire, de solutions de continuité, il y a des phases d'évolution rapide, où le paysage ancien se désagrège sous les regards du spectateur, pour laisser apparaîte l'ébauche d'um paysage nouveau, dont le temps précisera les contours et qui finira par régner sans partage. Que nous soyons dans une telle période, trop de signes l'attestent pour qu'il soit permis d'em douter. C'est ce qui fai aujourd'hui l'intérêt passionnant du droit international. C'est ce qui fait em même temps la dificulte de son étude" (Apud WEIL, 1992, p. 26).
} 
Ridruejo nas expressões "carências institucionais" e "politização alargada"7, poderiam ser mitigadas, mormente porque pressuporiam não a infirmação das jurisdições nacionais (rectius: soberania), mas na exigência de atuação concreta e institucionalmente adequada dos Estados na defesa dos valores e interesses comuns da humanidade, e que tem nos Direitos Humanos e na proscrição dos crimes internacionais, em especial os em stricto sensu (Genocídio, Crimes Contra a Humanidade, Crimes de Guerra e Crimes de Agressão), o locus central de conformação.

\section{A ACTIO POPULARIS NO DIREITO ROMANO}

O instituto de que cuida o presente trabalho tem sua origem situada no Direito Romano.

Para Aron X. Fellmeth e Maurice Horwitz, a actio popularis tinha por fundamento a ideia de que tanto o Estado como qualquer cidadão detinham legitimidade para pleitear judicialmente a proteção de interesses públicos, constituindo-se, nesse sentido, numa "qui tam action", expressão que tem origem na sentença "qui tam pro domino rege quam pro se ipso in hac parte sequitur", do que exsurge a ideia de uma corresponsabilidade e legitimidade concorrente entre cidadãos e o Estado. Esse "qui tam" constitui-se, portanto, no principalmente fundamento pelo qual a maior parte dos ordenamentos jurídicos da família romano-germânica, pelo menos em suas fases de regimes republicanos e/ou democráticos, têm assegurado actiones populares para que o cidadão proponha medidas judiciais que objetivam a tutela de interesses públicos (FELLMETH, HORWITZ, 2009, pp. 12 e 240).

No mesmo sentido asseverava M. Seabra Fagundes, para quem:

Ação popular é aquela por meio da qual o indivíduo provoca o pronunciamento do órgão judicante (em nosso regime político o Poder Judiciário) sobre atos ou abstenções da Administração Pública, que, não ferindo direito seu, afetem, de qualquer modo, o direito objetivo no que concerne aos serviços públicos, ao domínio do Estado, às servidões administrativas e às obrigações públicas. É instrumento posto a serviço dos membros da coletividade para o controle permanente da legitimidade extrínseca (e, às vezes, também intrínseca) do procedimento administrativo. No dizer de Gascon y Marin, completa o regime de direito

\footnotetext{
7 "Comparado com os Direitos internos dos Estados, o Direito Internacional Público se nos apresenta como uma disciplina especialmente problemática, caracterizada por umas denunciadas carências institucionais que causam incertezas e relativismos no plano normativo, graves insuficiências na prevenção e na sanção de [sua] violação e uma politização alargada - ainda que não absoluta - na solução de controvérsias, quando não na impossibilidade de sua resolução" (PASTOR RIDRUEJO, 2014, p. 23).
} 
a que se vincula a Administração Pública. Segundo Ranelletti, a ação popular pode ter sentido corretivo, se visa a reparar erro da Administração na realização do direito, e supletivo quando procura suprir a inércia da autoridade pública fazendo executar lei, cuja aplicação se descurou (FAGUNDES, 1946, pp. 1-2).

Para Adolf Berger, as actiones populares consistiam em:

[...] ações que podiam ser propostas por "qualquer um do povo" (quivis [quilibet] ex populus). Elas tiveram origem pretoriana, [e] objetivavam proteger o interesse público (ius populi). Eram de natureza Penal e, em caso de condenação do infrator, o demandante recebia a penalidade paga [...]. Contudo, algumas foram estabelecidas em leis ou Ordenações, em que a pena era paga para o Estado ou para o tesouro municipal, ou dividido entre o aerarium e o acusador, como, por exemplo, a prevista em um decreto do Senado para o caso de danos aos aquedutos (D. 47, 23) (BERGER, 1953, p. 347).

Contudo, para Egon Schwelb essa afirmação peremptória de que se constituíam essencialmente em ações de natureza penal não é certa. Com efeito, conforme Schwelb:

No direito romano, a actio popularis era uma ação que era proposta por qualquer membro do público (quivis ex "populo). As duas ações populares mais importantes e mais conhecidas descritas abaixo tinham certo elemento penal e de ordem pública [policing], mas não eram tanto "instituições do direito penal romano", mas parte do direito das obrigações. Surgiram no âmbito de ações originadas de quasi ex dellicto, [que] muitas vezes, não muito precisamente, [são] chamadas de "quasedelitos". Os assim chamados quase-delitos eram instituições não da antiga lei penal romana, mas da lei pós-clássica e, principalmente, do código Justiniano. Um quase-delito era um fato que, sem ser um delito, criava obrigações semelhantes às decorrentes de um delito, isto é, [a] responsabilidade de pagar indenização e, em determinados casos, responsabilidade criminal. A actio de deiectis vel effuses se movia em face do proprietário do imóvel de onde coisas tinham sido jogadas ou líquidos derramados, de modo a prejudicar as pessoas na rua. O proprietário também era responsável se seu escravo, convidado ou criança tivesse sido responsável pelo lançamento ou despejo. O pretor romano concedia a actio de posito et suspenso a todos os cidadão quando as coisas eram dispostas ou suspensas no exterior de uma casa ou numa janela de forma a pôr em perigo os transeuntes (SCHWELB, 1972, p. 47).

Esse problema pertinente à natureza da actio popularis no Direito Romano, isto é, saber se se constituíam em ações de caráter civil e/ou penal, pode ser solvido em duas obras do romanista Theodor Mommsen. A primeira, contida no volume 3 de suas Gesammelte Schriften, no qual consta um artigo sobre as Ações Populares [Popularklagen], e a outra no seu Direito Penal Romano, especificamente o Capítulo II, do Livro III, que trata do procedimento penal, intitulado "[D]As partes e da Assistência Jurídica no Procedimento Acusatório".

Em seu Ações Populares (MOMMSEN, 1907, pp. 375 e ss), o autor inicia seu trabalho contestando a opinião defendida por Brunswick segundo a qual o conceito de ação popular 
somente se aplicava àquelas demandas que poderiam ser propostas por qualquer do povo, mas desde que delas redundassem benefícios ou vantagens próprias, em especial a coparticipação na percepção das multas aplicadas. Mommsen aponta o equívoco dessa concepção ao sustentar que, segundo as fontes, popularis seriam aquelas ações que poderiam ser propostas por qualquer cidadão, e diversamente do que sustentado por aquele autor, por elas se tutelavam o interesse da comunidade ${ }^{8}$ e não interesses indiretos que poderiam ser aferidos pelo demandante. Confirma a hipótese mommseana o fato de o autor-popular, em caso de urgência, poder propor uma populare interdictum, que como toda medida dessa natureza ${ }^{9}$, tinha por função permitir a intervenção imediata do órgão competente (judiciário ou governamental, a depender da esfera de competência) para prevenir ou determinar a cessação de dano à coisa pública. Uma vez interposta a ação popular, uma consequência de seu acolhimento seria a determinação de restituição da res publica ao seu estado anterior, bem como a imposição de multa, de caráter civil ou penal, que poderia ou não ser atribuída ao autor popular.

Já no Capítulo II do Livro III de seu Direito Penal Romano (MOMMSEN, 1899, pp. 366 e ss), Mommsen informa que na segunda etapa histórica do processo penal romano, coincidente com a República, o antigo modelo inquisitorial fora substituído pelo sistema da actio, o que pressupôs a instituição de um sistema acusatório em que o juiz ocupava uma função equidistante das partes. Ora, se somente no período do Império surgirá a figura do procuratoris principis, a quem competia exercer a acusação? Di-lo Mommsen:

A base do procedimento acusatório era a seguinte: aquele que a propunha em representação à Comunidade [Vertretung der Gemeinde] em razão dos danos que the foram impingidos, uma pessoa tomava sobre si referido encargo e assumia referida responsabilidade, [mas] não de ofício, isto é, em razão de seu cargo,

\footnotetext{
8 "[...] popularis bezeichnet die Handlung, die von jedem Bürger vorzunehmen ist [...]. Als Motiv dieser Anordnung bezeichnen die Rechtslehre nicht, wie Bruns will den Vorteil des Klägers, sondern das Interesse der Gemeinde" (MOMMSEN, 1907, pp. 376-377).

9 "An order issued by a praetor or other authorized official (proconsul in the provinces) at the request of a claimant and addressed to another person upon whom a certain attitude is imposed: either to do something or to abstain from doing something. The interdictal procedure is more administrative than judicial in nature and differs from a normal trial in that there is no division of the proceedings into two stages inasmuch as the issuance of an interdictum depends upon the magistrate as an act of his imperium, not of jurisdiction. The interdictum is a provisory remedy with the purpose of protecting existing situations by a quick decision of the official. It fulfills ts task-a speedy ending of a controversy-only when the adversary complies with the order. If he does not, the subsequent procedure which assumes the form of a normal trial, though not without certain particularities resulting from the fact that an interdict had been issued, is rather complicated and perhaps even slower than an ordinary process" (BERGER, 1953, p. 507).
} 
mas por própria e livre resolução. Esta pessoa era o acusador ou demandante [...] O fato de não [se] exercer a ação ou demanda em razão do delito poderia dar origem a desvantagens jurídicas àquele que não a exercesse, enquanto que o seu exercício poderia produzir vantagens jurídicas ao acusados. Entretanto, não existia no direito meio coativo algum para obrigar alguém a interpor a ação, de modo que se nenhuma pessoa acusasse por sua própria vontade, o delito restava impune, salvo as hipóteses em que intervinha a cognitio [...] (MOMMSEN, 1899, p. 366).

Em síntese, portanto, se pode concluir que as ações populares no direito romano não eram identificadas pela natureza jurídica da causa - civil, quase-delito ou delito -, mas: a) pela legitimidade ativa atribuída a qualquer cidadão, b) pela natureza jurídica do interesse tutelado, a saber, coletivo [res publica] e c) pela intenção que movia o autor popular, isto é, preservar o interesse coletivo ante as insuficiências institucionais do regime jurídico, uma vez que, sem a sua intervenção, ele encontrava-se sob ameaça de dano.

Que o processo penal republicano se assentasse sobre a acusação popular como forma se evitar a impunidade, haja vista a inexistência de órgão público dotado de titularidade exclusiva para a ação, constitui-se em uma circunstância bastante significativa para se dilucidar a actio popularis tal como prevista no Direito Internacional contemporâneo, em especial no tema relativo aos crimes internacionais, já que, sem a atuação dos Estados no tocante ao binômio prevenção-persecução, remanesceria aquele fato que se pretendia evitar com a acusação popular, a saber, a impunidade.

\section{A INSERÇÃO DA ACTIO POPULARIS NO DIREITO INTERNACIONAL: OS CASOS ETIÓPIA E LIBÉRIA VS ÁFRICA DO SUL}

Conforme divisado nas linhas iniciais, até onde se pode divisar nas pesquisas efetuadas, a actio popularis ingressou nos debates do Direito Internacional a partir dos Casos Etiópia e Libéria v. África do Sul, julgados pela CIJ entre os anos de 1962 e 1964, tendo por substrato fático-jurídico as distorções promovidas pela África do Sul na execução do mandato de tutela outorgado pela Liga das Nações logo após o término da Primeira Grande Guerra Mundial.

Até então, o Sudoeste Africano constituía-se em colônia alemã, cuja ocupação se dera durante o II Reich sob o reinado do Kaiser Wilhelm I e a chancelaria de Bismark, que logo após a Conferência de Berlim se lançou à ocupação dos "espaços vazios" que restavam no continente africano. Vazio, no entanto, de ocupações coloniais europeias, uma vez que referido território era habitado pelas etnias herero e ovambo, sendo que aqueles se tornaram nas primeiras 
vítimas do "crime dos crimes" que se daria no continente europeu durante a Primeira (com os armênios) e a Segunda Grandes Guerras (com judeus e ciganos): o genocídio. Diga-se, somente de passagem, que só recentemente se reconheceu o genocídio contra os herero como tal. Mesmo um autor tão destacado em seus estudos acerca da origem do genocídio como Schabas, reconhece-o somente desde o armênio, e não antes, muito embora faça eco à famosa frase sartriana, segundo a qual "[...] o genocídio é tão antigo como o mundo" (SCHABAS, 2009, pp. 1 e ss).

O Sudoeste Africano somente conquistou sua independência da África do Sul em 1990, quando, após a luta pela descolonização, fortemente apoiada, em nível político, pelas Nações Unidas, e militarmente pela Angola pós-desconolonização, constituindo-se hoje na República da Namíbia (ENCICLOPÉDIA DO MUNDO CONTENPORÂNEO, 2002, pp. 434-436).

Como já dito, as demandas foram propostas em 04/11/1960 pela Etiópia e pela Libéria tendo por objeto o mandato outorgado à África do Sul pela Liga das Nações, e que em razão de este organismo ter sido sucedido pelas Nações Unidas, o mandato detinha a natureza de tratado internacional vigente, bem como os deveres e obrigações decorrentes do mesmo ${ }^{10}$. Em referidas reclamações, os Governos alegaram a jurisdição da CIJ com fundamento nos artigo 8o, I da Carta das Nações Unidas (doravante CONU), artigo 7 do Mandato e 37 do Estatuto da Corte Internacional de Justiça (doravante ECIJ). Tendo a África do Sul sido notificada para apresentar a sua defesa preliminar, em 30/11/1961 ela apresentou suas Objeções Preliminares, pelo que foram suspensos os procedimentos de análise do mérito. Nesse interregno, tanto os demandantes como a demandada apresentaram juízes ad hoc, nos termos do artigo 31, §3ㅇ do ECIJ.

A base da reclamação tinha por objeto o fato de que a África do Sul havia modificado de forma substancial e unilateral os termos do mandato outorgado pela Liga das Nações, bem como violado os deveres de prestação de contas mediante a apresentação anual de Relatórios às Nações Unidas, deixando de dar cumprimento a seus deveres de promover o bem-estar econômico e moral da população, mormente por ter instituído em referido território a política de Apartheid já vigente no seu território, práticas com as quais ela

[...] adotou e aplicou legislação, regulamentos administrativos e ações oficiais que suprim[iram] os direitos e as liberdades dos habitantes do

\footnotetext{
${ }^{10}$ É importante lembrar, ademais, que a CIJ já afirmara em outra ocasião que o mandato outorgado pela Liga das Nações à África do Sul constituía-se: a) em um tratado internacional, b) vigente e c) e que deveria ser cumprido de boa-fé por este Estado no contexto do sistema da Carta, conforme ficará as resoluções aprovadas pela AGONU por ocasião de sua Primeira Seção de 1946 (CIJ, 1950).
} 
Território, essenciais à sua evolução ordenada para o autogoverno, cujo direito é implícito no Pacto da Sociedade das Nações, aos termos do Mandato e aos padrões internacionais [...] aceitos, consagrados na Carta das Nações Unidas e na Declaração dos Direitos do Homem [...] (CIJ, 1962, p. 14).

O Juiz Bustamente, em seu voto em separado, destacou expressamente quais seriam esses direitos: liberdade pessoal e proibição de escravismo, liberdade de consciência e de religião, proibição de discriminação perante o Mandatário e acesso à educação, desenvolvimento econômico e independência política.

Nesse ponto, é importante citar as diversas Resoluções que Assembleia Geral das Nações Unidas (doravante AGONU) aprovou em sua Primeira Seção, no ano de 1946, acerca da absorção pela ONU de funções políticas ou não, acordos, tratados, bens etc existentes sob o regime da Liga das Nações, com especial ênfase na relação sistema de mandato (Liga das Nações) - sistema de tutela (ONU) ${ }^{11}$. Assim, esquematicamente, tem-se que: a) pela Resolução 9 (I) de 09/02/1946, a AGONU reconheceu que as sociedades sem capacidade de auto-governo constituam numa das principais causas de conflitos internacionais, pelo que assumiu a administração provisória dos regimes de mandato da Liga das Nações nos termos do artigo 79 da CONU, tendo decidido, doutro polo, pela criação da Comissão de Tutela; b) pela Resolução 24 (I), de 12/02/1946, a AGONU decidiu pela constituição de comissão interorganizacional de gestão do processo de transferência das atividades administrativas e políticas da Liga das Nações para a ONU, bem como os respectivos documentos, acordos, tratados, bens etc, dentre os quais se encontravam os acordos de relativos aos mandatos, ex vi da Resolução 51 (I), de 14/12/1946; pelas Resoluções 63, 64 e 65 (I), respectivamente, de 13 e 14/12/1946, a AGONU aprovou a criação do Conselho de Tutela (Resolução 63), e os Acordos de Tutela referentes aos territórios da Nova Guiné (Austrália), Ruanda-Urundi (Bélgica), parte do território de Camarões (França), parte do território de Togolândia (França), Samoa Oeste (Nova Zelândia), Tanganica (Reino Unido), parte do território de Camarões (Reino Unido) e parte do território de Togolândia (Reuno Unido) (Resolução 64). No que toca à Resolução 65, a AGONU indeferiu o pedido formulado pelo Governo da África do Sul de anexar o território do Sudeste da África e, reportando-se às Resoluções 63 e 64, concitou a África do Sul a apresentar à AGONU projeto de Acordo de Tutela sobre o território, bem como que ela, enquanto não provisse o projeto e ele fosse aprovado, continuasse a execer, de conformidade com o Mandato outorgado pela Liga das Nações, a administração do território.

\footnotetext{
${ }^{11}$ As resoluções foram consultadas no seguinte sítio http://research.un.org/en/docs/ga/quick/regular/1, acessados em 22.JAN.2016, às 14:00.
} 
A África do Sul, em sua Defesa Preliminar, alegou que os dois Estados não detinham locus standi para promover o contencioso, sendo que em suas sustentações orais reforçou referida ideia ao infirmar a existência de jurisdição da CIJ para julgar a contenda, mormente porque: a) com a dissolução da Liga das Nações, o Mandato decaira de vigência; b) que tanto a Liberia como a Etiópia, por não terem sido membros da Liga das Nações, careciam de locus standi para pleitear a jurisdição da Corte no que tange ao Mandato e c) que a Liberia e a Etiopia careciam de interesse processual na interposição da reclamação internacional, seja porque o território do Mandato não pertencia a nenhum desses Estados nem apresentava qualquer violação a direitos de seus nacionais.

Na primeira fase, portanto, a ClJ apreciou a arguição de incompetência da Corte tendo por parâmetro, de um lado, a alegação dos proponentes, que o fizeram, como visto, a partir da combinação dos artigos 8o, I da CONU, 7 do Mandato e 37 do ECIJ, e de outro lado aferir se a Etiópia e a Libéria detinham, de fato, locus standi, mormente a partir do precedente advindo do caso Mavrimmatis Palestine Concessions da Corte Permanente de Justiça Internacional (doravante CPIJ), segundo o qual, o locus standi adviria da existência de uma desavença [disagreement] "[...] on a point of law or fact, a conflict of legal views or interests between two persons" (CIJ, 1962, p. 22), cuja aferição deveria ser encontrada no caso concreto desde a sua facticidade histórica e da oposição jurídica que a pretensão de fato ou de direito concretiza, e não, somente, dos argumentos que as partes em litígio enunciavam.

Para a ClJ, a existência da lide encontrava-se perfeitamente clara ante a desavença acerca dos cumprimento dos termos do mandato pela África do Sul, uma vez que o mandato, tendo sido conferido pela Liga das Nações, tinha por fundamento [...] o reconhecimento de determinados direitos [comum a todos os] povos [para os] povos de um território subdesenvolvido; o estabelecimento de um regime de tutela por uma nação desenvolvida como [um] mandato em nome da Liga das Nações; o reconhecimento de uma "sagrada confiança da civilização" [sacred trust of civilisation] outorgado à Liga como comunidade internacional organizada e aos Estados membros. Este [sistema de Mandato é] dedicado ao objetivo declarado de promover o bem-estar e o desenvolvimento de tais povos, reforçado por meio da criação de salvaguardas para a proteção de seus direitos (CIJ, 1962 p. 24). Nesse sentido, os interesses e poderes que o mandatário recebia se constituiam em meros instrumentos [tools] para a fiel execução dos objetivos desse instrumento. Em outros termos, ao assumir o mandato, assumia eo ipso os deveres e obrigações inerentes ao regime, não the subsistindo qualquer interesse externo a seu fiel cumprimento perante a comunidade internacional e a Liga das 
Nações, quais sejam, a de prestar, anualmente, contas do mandato e a implementação de seus cláusulas fundamentais, e de outro lado, a de exercê-lo de conformidade com a "sagrada confiança da civilização".

No que tange à natureza jurídica do mandato, a CIJ reconheceu, expressamente, constituir-se em tratado internacional celebrado entre a África do Sul e o Conselho da Liga das Nações, e que se distanciava dos tratados internacionais anteriores pelo fato de ter sido celebrado não entre dois Estados, mas entre um Estado e uma Organização Internacional, sendo que, em razão da absorção da Liga das Nações e da CPIJ pela ONU e a CIJ, referido mandato encontrava-se sob a autoridade daquela primeira e sob a jurisdição dessa última, e uma vez que os litigantes eram membros da $\mathrm{ONU}$, bem como aceitaram a jurisdição da $\mathrm{ClJ}$, ao ratificarem o seu Estatuto, a jurisdição contenciosa prevista no artigo 70 do mandato poderia ser exercida pela CIJ.

No que tange ao tema do locus standi, a ClJ considerou-a presente em razão de: a) o regime jurídico do mandato pressupor não somente a tomada de contas pelas então Comissão Permanente de Mandatos e a Assembleia Geral da Liga das Nações, mas também pelos Estados membros, que podiam requerer informações adicionais quanto ao seu cumprimento, sendo que, na opinião da Corte, a única forma efetiva de se proteger esse regime era a de um Membro ou Membros da Liga invocar o artigo 7 e apresentar uma demanda contra o Mandatário invocando a jurisdição da CPJI, sendo que, em razão de a Liga das Nações ter sido absorvida pela ONU, referidos direitos, obrigações e jurisdição continuavam em vigência em razão do princípio geral do direito da continuidade dos mandatos, e que fora direta ou indiretamente reconhecido pelos Estados que participaram das discussões na AGONU quando do debate acerca da assunção de tais mandatos por este organismo.

Nesse sentido, a afirmação de que os Estados demandantes detinham locus standi para provocarem a jurisdição contenciosa da Corte se submia na ideia de que, ao atuarem como membros da comunidade internacional, com o objetivo de, um lado, assegurar o fiel cumprimento do mandato fundado sobre a "sagrada confiança da civilização", e que tinha, por outro lado, o objetivo declarado de promover o bem-estar e o desenvolvimento dos povos submetidos a referido regime, o que era reforçado pela criação de salvaguardas para a proteção de seus direitos, os Estados agiam na forma de uma actio popularis, vale dizer, objetivavam não a tutela de um interesse particular, mas de interesses comuns da sociedade internacional que estavam sendo violados tanto pela ausência de prestaçao de contas pelo mandatário, como pelo estabelecimento de uma política de Estado, que em período posterior veio a ser 
considerada como genuíno crime internacional próprio - conforme previsto no International Convention on the Suppression and Punishment of the Crime of Apartheid, de 1973.

Entretanto, é importante frisar que, diversamente do que se poderia esperar, a expressão actio popularis somente foi empregada pelo então Presidente M. Winiarski para negar que os Estados demandantes detinham locus standi, pois, em sua concepção, o Direito Internacional não o reconhecia como instituto vigente nem em 1919-1920, nem à época do julgamento das questões preliminares:

The characteristic feature of this alleged supervision was that it could be brought into operation by any Member of the League which considered that there existed between it and the mandatory administration "a disagreement on a point of law or fact, a confict of legal views" on the way in which the Mandatory was exercising its Mandate. Reference has been made in this connection to an institution under the old Roman penal law known as "actio popularis" which, however, seems alien to the modern legal systems of 1919-1920 and to international law. 1s it possible that such can have been the common intent of the framers of the Mandate instruments? There is no evidence for it, it has been asserted without any attempt to show that it was so; on the contrary, it would seem that the circumstances in which the Mandate was established exclude such an eventuality.

Por fim, o último ponto alegado pela África do Sul na infirmação da jurisdição da Corte a de que não existiria um litígio entre os demandantes, mormente porque desde 1946 ela se encontrava em processo de negociação diplomática com as Nações Unidas para estabeleber o Acordo nos termos do sistema de tutela, e que portanto, a Etiópia e a Libéria também participavam dessas deliberação na forma de Estados membros da ONU -, a Corte o rechaçou sob o argumento de que, seja com a propositura da demanda seja nos procedimentos orais, restou clara a existência de uma lide em torno à execução do mandado, não subsumível nem abrangido pelas negociações coletivas havidas na ONU.

Assim, por oito votos a sete, a CIJ, afastando as objeções formuladas pela África do Sul, declarou-se competente para julgar as demandas propostas pela Libéria e a Etiópia.

Contudo, na segunda fase de julgamento do caso em 1966, a Corte, seguindo o voto proferido pelo então Juiz-Presidente M. Winiarski quando da apreciação das Objeções Preliminares, decidiu, por maioria, não conhecer das reclamações propostas pelos Estados, conforme resta evidenciado na Ementa da decisão:

Alleged contraventions of League of Nations Mandate for South West Africa - Question of the legal status of the Applicants-Status governed by their position as former members of the League - Antecedent question arising on the merits of the case whether Applicants, as individual States former members of the League, have any legal right or interest in the 
subject-matter of their claim - Character of the mandates system within the framework of the League-Effect of Article 22 of the League Covenant instituting the system generally - Obligations of each mandatory defined its particular instruments of mandate - Structure of these instruments Clauses conferring in respect of the mandated territory direct commercial or other special rights on League members its their capacity as separate States - Clauses providing for the carrying out of the mandate as a "sacred trust of civilization" in regard to the inhabitants of the territoryMandatory's obligations under latter class of clauses owed to League as an entity, not to member States individually - Lack of any legal right for member States individually to claim performance of these obligations Additional rights not acquired by reason of dissolution of the League.

Political, moral and humanitarian considerations not in themselves generative of legal rights and obligations.

Jurisdictional clause of the mandates - Effect of decision given by the Court in 1962 on the question of ifs competence - Relationship between decisions on a preliminary objection and any question of merits -Inability in principle of Jurisdictional clauses to confer substantive rights - Capacity to invoke a jurisdictional clause does not imply existence of any legal right or interest relative to the merits of the claim - Interpretation of jurisdictional clause of the mandates - Jurisdictional clauses of the minorities treaties not comparable - Analysis of League practice in respect of mandates - Inconsistency with existence of rights now claimed by the Applicants.

Functions of a court of law - Limits of the teleological principle of interpretation - Court not entitled by way of interpretation to revise, rectify or supplement (CIJ, 1966).

A Corte, portanto, ao afirmar que "[...] [c]onsiderações políticas, morais e humanitárias, por si só, não geram direitos e obrigações legais [...]" a se legitimar a propositura das demandas, negou a vigência e a incidência da actio popularis no contexto do Direito Internacional.

\section{EGON SCHWELB E A CRÍTICA À DECISÃO DA CIJ}

Parece não existir dúvida razoável no que toca à natureza da discussão acerca da vigência da actio popularis no Direito Internacional no contexto dos casos Etiópica e Libéria v. África do Sul: tratou-se de aferir, em suas duas fases, se este instituto constituía-se em um princípio geral do direito reconhecido pelas nações civilizadas, nos termos do artigo 38, 1, "c" do ECIJ, do que decorreria a legitimidade para que os dois Estados demandassem face à África do Sul objetivando a tutela jurisdicional não de seus interesses nacionais, mas a preservação da "sagrada confiança da civilização" expressa no Mandato. Verificou-se, nesse sentido, que segundo a concepção da maioria da Corte, seguindo o voto dissidente proferido pelo então JuizPresidente M. Winiarski na primeira fase do julgamento, que não, mormente por ter 
considerado que, repitamos, "[...] [c]onsiderações políticas, morais e humanitárias, por si só, não geram direitos e obrigações legais [...]".

Em crítica a essa decisão da CIJ, Egon Schwelb publicou em 1972 um de seus muitos trabalhos com os quais granjeou destaque na comunidade internacionalista - The Actio

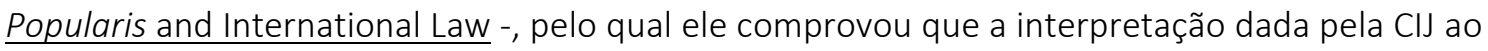
instituto era equivocada, principalmente porque os muitos tratados internacionais vigentes sobre matérias como o Direito Penal Internacional e Direito Internacional dos Direitos Humanos se assentavam, como forma de prevenção/repressão às graves violações ao Direito Internacional, sobre o a corresponsabilidade e colegitmidade para a tutela jurisdicional de referidos interesses e valores comuns (SCHWELB, 1972). Contudo, seguindo as trilhas lançadas por Alfred P. Rubin, parece ser exagerado afirmar-se que se possa atribuir a Schwelb a "paternidade" ou mesmo a "primazia" na inserção da actio popularis no Direito Internacional, mesmo porque, como visto, o seu texto é uma crítica ao julgamento da $\mathrm{CIJ}$, na qual o problema do reconhecimento internacional do instituto já fora discutido (RUBIN, 2000/2001, p. 268).

Ademais, Schwelb não foi o único nem o primeiro a discutir os muitos problemas decorrentes da decisão da CIJ. Prott, por exemplo, discutiu as muitas dificuldades enfrentadas pela Corte já na primeira fase, uma vez presentes desde a própria complexidade da matéria julgada, a heterogeneidade da composição da Corte, isto é, juízes advindos de culturas jurídica distintas - common law, civil law, direito soviético, direitos islâmico e asiático -, o manifesto caráter político-jurídico das pretensões postas em juízo, pelo que considerou que referida decisão constitui-se, para o Direito Internacional, como uma sorte de "[...] Rubicon, not only because of the uncommon nature and of the importance of the issues involved, but also because the most fundamental matters of function and method were wrestled with [...]", especialmente no tocante aos próprios limites da atuação da Corte e na manifesta contraposição que se estabeleceu entre os partidários de um intervenção orientada por princípios (a maioria), face à minoria que se orientou, na linha dos votos dissidentes dos Juízes Fitzmaurice e Spender Jr, por uma interpretação legalista (PROTT, 1967, pp. 37-51).

Já MacKean, em um trabalho cindido em duas partes, enfrentou os problemas advindos do julgamento da seguinte forma. Na primeira parte de seu trabalho, intitulado "Legal right or interest" in the South West Africa Cases (MacKean, 1966, pp. 135-141), ele criticou, de um lado, o fato de a segunda fase de julgamento do caso ter chegado a uma conclusão diametralmente oposta àquela ocorrida na fase inicial, tendo-se em vista que, para tanto, a CIJ se utilizou da máxima pas d'interêt, pas d'action, uma vez que considerou inexistente a presença de interesse 
jurídico da Etiópia e da Libéria para demandar face à África do Sul, e de outro lado, o fato de a própria Corte ter considerado como razão de decidir na primeira fase que a essência do regime de mandato era que os Estados Membros, e não só o Estado e a Organização Internacional, terem interesse jurídico no adimplemento das cláusulas dos mandato, do que dessumiria, nesse sentido, o reconhecimento e aplicação do instituto da actio popularis na forma de um princípio geral do direito reconhecido pelas nações civilizadas ${ }^{12}$. Já na segunda parte de seu trabalho - $\underline{A n}$ examination of Certain Criticism of The South West Africa Cases Judgment (MACKEAN, 1966, pp. 143-148), MacKean apresenta algumas perplexidades que a comunidade de juristas australianos - internacionalistas e constitucionalistas - sentiram com relação à segunda fase do Julgamento, em especial no tópico relativo à não aplicação da actio popularis, na medida em que, tanto no âmbito da equity como do direito constitucional australianos, ser amplamente reconhecido a legitimidade para particulares proporem ações na defesa de interesses públicos, quanto mais em razão de a "[...] International Court of Justice erred in so far as it refused to regard itself as bound by its decision in 1962, on the preliminary objection to jurisdiction, when it ruled that the applicants were entitled to invoke the Court's jurisdiction" (MACKEAN, 1966, p. 144).

Seja como for, há que se reconhecer, no entanto, ser o trabalho de Egon Schwelb bastante didático e preciso na crítica à decisão proferida pela $\mathrm{CIJ}$, na medida em que, conforme por ele demonstrado, o Direito Internacional reconhecia a aplicação da actio popularis já no âmbito de diversos tratados internacionais do período do entre guerras, como, por exemplo, o capítulo III do Tratado de Versalhes, que constitui a Organização Internacional do Trabalho (anterior, portanto, ao Mandato discutido na caso), segundo a qual qualquer Estado membro poderia demandar perante a CPJI face a um terceiro Estado que não estivesse a cumprir tratados internacional ratificados sob a autoridade da Organização (artigo 411 do Tratado de Versalhes c/c artigo 26 da Constituição da OIT). O mesmo no âmbito dos Tratados Internacionais para a Proteção de Minorias, e que haviam sido pactuados pelos litigantes com o término da Primeira Guerra Mundial.

12 Of course, in the South West Africa Cases, the applicants were not strictly speaking parties to the Mandate agreement but were exercising rights under stipulations per autrui (though this is doubted by some of the minority judges). The Mandates were concluded by the League Council on behalf of its members and the Mandatories. As Judges Jessup, Tanaka, and Mbanefo show in their dissenting opinions, there are clear analogies in municipal law, where members of certain organizations have enforceable legal interests apart from those exercised by the organizations themselves. Moreover in the present circunstances, only States could be parties in contentious proceedings before the Court, the only method of obtaining a binding decision concerning the interpretation and application of the Mandate. (MACKEAN, 1966, p. 138). 
Já no sistema da Carta, segundo Schwelb, a essência dos tratados internacionais em matéria de Direito Penal Internacional - Convenção sobre a Prevenção e Punição ao Genocídio, em especial na representação de reclamação perante a AGONU ou o CSONU, mas também em matéria de interpretação ou aplicação de cláusulas do Tratado mediante reclamação judicial perante a $\mathrm{CIJ}$ - ou de Direito Internacional dos Direitos Humanos, regionais ou universais - a Convenção Europeia e a Americana; Protocolo à Convenção Contra a Discriminação na Educação, de 1962, Convenção Internacional para a Eliminação de Todas as Formas de Discriminação etc, reconheceu-se aos Estados Partes a legitimidade para judicializar hipóteses de graves violações ao Direito Internacional, ou mesmo exercer a persecução penal dos autores de conformidade com o seu próprio sistema de justiça. Para tanto, Schwelb se reportou à decisão da própria CIJ na Segunda Fase do caso Barcelona Traction, no qual a Corte fixou as bases das obrigações erga omnes:

[...] an essential distinction should be drawn between the obligations of a State towards the international community as a whole, and those arising vis-à-vis another State in the field of diplomatic protection. By their very nature the former are the concern of al1States. In view of the importance of the rights involved, al1 States can be held to have a legal interest in their protection; they are obligations erga omnes.

Such obligations derive, for example, in contemporary international law, from the outlawing of acts of aggression, and of genocide, as also from the principles and rules concerning the basic rights of the human person, including protection from slavery and racial discrimination. Some of the corresponding rights of protection have entered into the body of general international law [...]; others are conferred by international instruments of a universal or quasi-universal character (CIJ, 197), p. 33).

A mesma Corte que, ainda no ano de 1951, por ocasião do Parecer Consultivo acerca das Reservas à Convenção sobre o Genocídio anotara a distinção entre o objeto de referida Convenção em relação àqueles presentes, e.g., em matérias de interesses particulares dos Estados, uma vez que os

[...] princípios nos quais ela se fundamenta são reconhecidos pelas nações civilizadas, como obrigatórios aos Estados, independentemente de serem normas de uma Convenção Internacional; ela foi concebida como uma convenção de alcance universal; sua finalidade é puramente humana e civilizadora; os contratantes não auferem nem vantagens, nem desvantagens individuais; nem interesses próprios, mas um interesse comum. De onde é permitido concluir-se que o objeto e a finalidade da Convenção implicam, tanto no que respeita à Assembleia Geral, quanto aos Estados que a adotam, a intenção de reunir o maior número possível de participação (CIJ, 1951, p. 7). 
Nesse sentido, pode-se colher como correta a crítica de Schwelb à decisão da CIJ na Segunda Fase do caso Etiópia e Lívia v. África do Sul, segundo a qual, o Direito Internacional reconhecia a actio popularis como instituto válido tanto "[...] em 1919/1920, [como] em 1962 e 1966, assim como hoje" (SCHWELB, 1972, p. 55).

\section{ACTIO POPULARIS, A MÁXIMA AUT DEDERE AUT JUDICARE, DIREITO PENAL INTERNACIONAL E A IMPLEMENTAÇÃO INDIRETA DA PERSECUÇÃO PENAL DE CRIMES INTERNACIONAIS}

Nesse tópico, o tema principal a ser abordado toca no problema dos regimes de persecução dos crimes internacionais, próprios e transnacionais, bem como nas formas de implementação previstas no Direito Penal Internacional contemporâneo, em especial no chamado regime de implementação indireta, conformado pela regra aut dedere aut judicare e pela actio popularis.

No que concerne ao conceito de crimes internacionais, como já dito em outra oportunidade:

Denomina-se crime internacional qualquer comportamento humano a que uma norma internacional, convencional ou consuetudinária, atribua, como uma consequência de sua realização, uma sanção penal, sendo que a persecução penal poderá ser exercida pelos próprios Estados, de conformidade com os seus ordenamento jurídicos, seja pelos tribunais penais internacionais. (DE OLIVEIRA, 2016, pp. 428-429)

Como seja, conforme M. Cherif Bassiouni, "Os aspectos penais do Direito Internacional derivam das "convenções", "costumes" e "princípios gerais do direito", todos os quais são uma das fontes dessa disciplina jurídica tal como enunciado no artigo 38 do Estatuto da Corte Internacional de Justiça" (BASSIOUNI, 2013, p. 9).

Já por formas de implementação do Direito Penal Internacional entende-se os diferentes regimes normativos e institucionais pelos quais a persecução penal dos crimes internacionais é exercida (BASSIOUNI, 2013, p. 22), e que implicam, de um lado, na preservação, embora mitigada, da jurisdição penal dos Estados, e de outro lado na criação, como regra geral, de mecanismos de complementação ou concorrência entre jurisdições estatais e internacionais e ou entre jurisdições estatais.

Conforme Werle, "[O] Direito Internacional Penal faz uma distinção entre mecanismos de persecução (enforcement) direta ou indireta. Aqueles se referem à persecução dos crimes internacionais pelos tribunais internacionais, de um lado, ou pelas cortes nacionais, de outro lado" (WERLE, 2009, pp. 80-81), o que leva, em razão da possibilidade de ocorrer, em 
determinadas circunstâncias, conflito jurisdicional entre tribunais nacionais ou entre tribunais nacionais e tribunais internacionais, a aplicação de critérios de solução desse conflito.

Pois bem. Estes regimes instituídos pelo Direito Internacional objetivam, em última instância, colmatar a lacuna de punibilidade fática a que muitos crimes internacionais estão submetidos em razão da prevalência da realpolitik ou mesmo da impotência de muitos Estados em fazerem frente à criminalidade organizada, política ou econômica, sobre a necessidade de preservação da autoridade normativa do direito e a efetiva proteção dos bens e interesses comuns da sociedade internacional (AMBOS, 2004, pp. 48-88; AMBOS, 2008, p. 40).

Assim, internacionalmente existem dois regimes de implementação do Direito Penal Internacional.

O primeiro é o sistema da implementação direta (direct enforcement system), cujo exercício da persecução penal se dá pelos tribunais penais internacionais, e que se caracteriza pelo "[...] regime aplicável às instituições judiciais internacionais que têm o poder para executar seus mandatos (have the power of enforcing their orders) e julgamentos sem passar pelos Estados ou qualquer outra autoridade legal" (BASSIOUNI, 2013, p. 22). Esse regime é criado por normas internacionais, sendo os tribunais compostos exclusivamente de juízes internacionais, estando as suas competências materiais delimitadas à persecução de crimes internacionais próprios.

Outra característica importante do regime de implementação direta é a de que até a entrada em funcionamento do Tribunal Penal Internacional, em 2002, todos os Tribunais Internacionais que existiram foram ad hoc, vale dizer, criados especificamente para exercer a persecução penal de eventos históricos concretos.

Historicamente, nada obstante a tentativa pós 1a Guerra Mundial de se submeter ao Kaiser Guilherme II da Alemanha a julgamento perante um tribunal penal internacional por "crimes contra a moral internacional e a autoridade sagrada dos Tratados", nos termos do artigo 227 do Tratado de Paz de Versalhes (JAPIASSÚ, 2004, p. 40), ao lado de outros projetos internacionais (FERREIRA DE ALMEIDA, 2009, pp. 26-27), o sistema de implementação direta se manifestou, concretamente, com a criação dos Tribunais Internacionais Militares de Nuremberg e Tóquio no pós 2a GGM, cujos Estatutos foram responsáveis, em parte, pela tipificação internacional dos crimes internacionais próprios ${ }^{13}$. Com efeito, por estas normas, referidos tribunais detinham competência para o julgamento dos indivíduos qualificados,

\footnotetext{
${ }^{13}$ Nuremberg pode, de fato, ser considerado como "[...] the birth certificate of international criminal law" (WERLE, 2009, p. 7).
} 
respectivamente, como os maiores criminosos de guerra do eixo europeu e do Japão durante a 2a GGM (Estatuto do Tribunal Militar de Nuremberg, doravante ETIMN, artigo 1o; Estatuto do Tribunal Internacional Militar do Extremo Oriente, doravante ETIMEO, artigo 1으, e aos quais se imputaram a prática dos crimes contra a paz, atualmente conformado no crime de agressão (ETIMN, artigo 6, a; ETMIEO, artigo 5, a), crimes de guerra (ETIMN, artigo 6, b; ETIMEO, artigo 5, b) e crimes contra a humanidade (ETIMN, artigo 6, c; ETIMEO, artigo 5, c). O crime de genocídio somente foi criado com a aprovação no ano de 1948 da Convenção sobre Genocídio, sendo que os comportamentos levados a julgamento em Nuremberg, e que em mencionada convenção se tipificariam como tal, foram perseguidos na modalidade de crimes contra a humanidade consistentes [...] no assassinato, extermínio e outros atos desumanos cometidos contra qualquer população civil, ou a perseguição por motivos religiosos, raciais" (SCHABAS, 2009, pp. 38-48).

Apesar de todos os problemas de legitimidade suscitados pelos julgamentos de Nuremberg ${ }^{14}$, na medida em que ao julgamento dos "maiores criminosos de guerra do eixo", identificado pelo termo jubiley - Tribunal Militar Internacional vs Hermann Göring et all -, se seguiram outros por categorias de agentes do regime político nacional-socialista, dentre eles juristas, médicos, industriais etc, feitos no bojo dos "Processos de Guerra de Nuremberg", e a partir não mais do ETIMN, mas da Control Council Law no $10^{15}$, que foi a base normativa para o julgamento dos acusados de crimes internacionais por tribunais militares nas zonas ocupadas pelos aliados ${ }^{16}$.

É importante demarcar que, internacionalmente, com a aprovação AGONU da Resolução 95 (I), de 11 de dezembro de 1946, com a qual se confirmaram os princípios do

\footnotetext{
${ }^{14}$ Em síntese, conforme J. Spiropoulos, as principais acusações que se levantaram contra Nuremberg foram as seguintes: "a) que se tratava de Tribunal ad hoc; b) que os julgamentos foram mais políticos do que jurídicos; 3) que apenas as quatro potências vitoriosas criaram o Tribunal, e, por consequência, que elas não representavam a comunidade internacional; e 4) que houve ofensa ao princípio da legalidade (nullum crimen, nullum poena sine lege)" (UM, CDI, 1950, pp. 374-378).

${ }^{15}$ CONTROL COUNCIL LAW N. 10, disponível em Disponível em http://avalon.law.yale.edu/imt/imt10.asp, acessado em 20.JAN.2012, às 10:00.

16 "Especificamente, os julgamentos incluem o assim chamados Julgamento dos Médicos (Brandt et al.), o julgamento do Marechal de Campo Erhard Milch por participação no programa de rearmamento, o Julgamento dos Juristas (Altstötter el al.), o julgamento dos membros dos departamentos econômicos e administrativos da SS, nos quais estão incluídos o das administrações dos campos de concentração (Pohl et al.), o julgamento dos Indutriais (Flick et al.), o assim chamado Julgamento IG Farben (Krauch et all.), o denominado Julgamentos dos Reféns (List et al.), o julgamento dos membros do Escritório de Depuração Racial (Race and Settlement Main Office) (RuSHA, Greifelt et al.), o denominado julgamento Einsatzgruppen (Ohlendorf et al.) [...] e o denominado Julgamento do Alto Comando contra os oficiais superiores da Wharmacht (von Leeb et al.)." (WERLE, 2009, p. 13).
} 
Direito Internacional reconhecidos pela Carta do Tribunal de Nuremberg, seguida da Resolução 177 (II), de 21 de novembro de 1947, que determinou à Comissão de Direito Internacional (doravante CDI) a formulação desses princípios, bem como, por fim, com o cumprimento desse comissionamento a partir do Relatório apresentado por J. Spiropoulos em 1950, foram estabelecidos os "Princípios do Direito Internacional Reconhecido pela Carta do Tribunal de Nuremberg e nos Julgamentos desse Tribunal", segundo os quais:

Princípio I: Toda pessoa que cometa um ato que constitua crime de Direito Internacional é por ele responsável e está sujeito a sanção.

Princípio II: O fato de que o direito interno não imponha pena alguma por um ato que constitua crime de Direito Internacional não exime de responsabilidade perante $\mathrm{o}$ Direito Internacional a quem o tenha cometido.

Princípio III: O fato de que a pessoa que tenha cometido um crime que constitua crime de Direito Internacional tenha atuado como Chefe de Estado ou como autoridade do Estado, não a exime de responsabilidade conforme o Direito Internacional.

Princípio IV: O fato de que uma pessoa tenha atuado em cumprimento de uma ordem de seu Governo ou de seu superior hierárquico não a exime de responsabilidade conforme o Direito Internacional, se efetivamente teve a possibilidade moral de opção.

Princípio V: Toda pessoa acusada de um crime de Direito Internacional tem direito a um juízo imparcial sobre os fatos e sobre o direito.

Princípio VI: Os crime a seguir enunciados são puníveis como crimes de Direito Internacional: a. Crimes contra a paz: i) planejar, preparar, iniciar ou fazer uma guerra de agressão ou uma guerra que viole a tratados, acordos e garantias internacionais; ii) participar de um plano comum ou conspiração para a perpetração de qualquer dos atos mencionados no inciso i; b. Crime de guerra: as violações às leis de guerra, que compreende, sem que esta enumeração tenha caráter limitativo, o assassinato, o maltrato ou a deportação para trabalhar em condições de escravidão ou com qualquer outro propósito, da população civil dos territórios ocupados ou que neles se encontre, o assassinato ou maltrato de prisioneiros de guerra ou de pessoas que se encontrem no mar, a execução de reféns, o saque da propriedade pública ou privada, a destruição injustificada de cidades, vilas ou aldeias, ou a devastação não justificada pelas necessidades militares; c) Crimes contra a humanidade: 0 assassinato, o extermínio, a escravização, a deportação e outros atos desumanos, cometidos contra qualquer população civil, ou as perseguições levadas a cabo ao se perpetrar um crime contra a paz ou um crime de guerra, ou ele relacionado.

Princípio VII: A cumplicidade na comissão de um crime contra a paz, de um crime de guerra ou de um crime contra a humanidade, enunciados no Princípio $\mathrm{VI}$, constitui por si mesmo um crime de Direito Internacional.

Com essas normas internacionais, às quais se seguiu em 26 de novembro de 1968 a aprovação, pela AGONU, da Convenção sobre a Imprescritibilidade dos Crimes de Guerra e dos Crimes contra a Humanidade, ao lado de tantos outros instrumentos internacionais, em 
especial a Carta Internacional de Direitos Humanos e as diversas convenções internacionais, universais e regionais sobre esta matéria, o Direito Internacional dotou-se de um conjunto de normas internacionais convencionais e costumeiras que tornam legítimas, para longe de qualquer dúvida razoável, as persecuções aos crimes internacionais próprios.

Hoje, passados largos anos desde Nuremberg e Tóquio, posto que em razão da bipolaridade leste-oeste conformada na Guerra Fria o sistema de persecução direta foi submetido a um verdadeiro "silêncio" (BASSIOUNI, 2013, pp. 565-566; BAZELAIRE, CRETIN, 2004, pp. 41-42), ele se manifestou novamente com a criação, por resoluções do CSONU dos então Tribunal Penal Internacional para a Ex-lugoslávia e Ruanda, hoje reunidos na forma de Câmaras no Mecanismo Residual dos Tribunais Penais Internacionais ${ }^{17}$. Em 1998, na Conferência Diplomática de Roma, foi aprovado, não sem muita luta ${ }^{18}$, o Tribunal Penal Internacional, e que se constitui, a todo rigor, numa das maiores conquistas civilizacionais do Direito Internacional contemporâneo, posto que, de um lado, concretiza o projeto internacional de constituição de um tribunal penal internacional permanente, e de outro, principalmente no plano do direito material, consolida e aperfeiçoa os tipos penais de Direito Penal Internacional em nível formal, muito embora não exclua eo ipso a aplicação da analogia e dos costumes internacionais sobre o tema (AMBOS, 2008, pp. 42-47; WERLE, 2009, pp. 18-25).

Contudo, este regime também abarca os chamados tribunais internacionais mistos (mixed-model tribunals), cuja composição, diversamente do que ocorre nos tribunais penais internacionais em sentido estrito, é de juízes nacionais e internacionais. Têm em comum com os tribunais penais internacionais pré-TPI a característica de serem ad hoc, criados, pois, para a persecução de crimes internacionais próprios em seus Estados sede, constituindo, pois, como uma etapa da justiça de transição em relação a períodos anteriores nos quais ocorreu o

\footnotetext{
17 Através das Resoluções 1503, de 25 de maio de 2003 e 1534, de 26 de março de 2004, o CSONU aprovou a "estratégia de conclusão" para os TPIY e TPIR, pondo como termo o final de 2004 para o encerramento das investigações, o final de 2008 para a conclusão dos julgamentos em primeira instância e o final de 2010 para o encerramento de todas as atividades judicantes. Como referidos prazos não foram cumpridos, o CSONU aprovou a Resolução 1966, de 22 de dezembro de 2010, instituindo o MRITP, cujo EMRITP seguiu anexo à Resolução, conformado por duas subdivisões, uma relativa ao TPIR, que começou a funcionar em 1 de julho de 2012, e outra do TPIY, que começou a funcionar em 1 de julho de 2013, que passaram a exercer as funções jurisdicionais internacionais de competência daqueles tribunais (UN, CSONU, 2010).

18 "As lágrimas de alegria dos membros de algumas delegações da Conferência de Roma que deu origem ao estatuto da CPI em julho de 1998 podem levar a crer que, no combate eterno do indivíduo contra a razão dos Estados, Antígona levou uma vantagem decisiva sobre Creonte". (BAZELAIRE, CRETIN, 2004, p. 111).
} 
cometimento de crimes internacionais próprios e graves violações aos direitos humanos (COSTI, 2005)

A principal característica desses tribunais é o fato de serem instituídos por meio de acordos internacionais, sejam entre os Estados e a AGONU ou organismo regional, ou por resolução do CSONU - que são as hipóteses de Serra Leoa e Líbano -, ou por organismo de transição instituído pelo CSONU, que é o caso de Timor Leste. Têm por direito substancial tanto as normas de Direito Penal Internacional, nomeadamente, os crimes de genocídio, contra a humanidade e crimes de guerra, como também, em muitos casos, o Direito Penal nacional dos Estados sede, o que tem provocado, na opinião de M. Cherif Bassiouni, uma "[...] inconsistência nas normas de Direito Internacional costumeiro, principalmente em relação aos crimes contra a humanidade que, diferentemente dos crimes de guerra e genocídio, não tem uma convenção unificadora" (BASSIOUNI, 2013, p. 23).

O outro sistema internacional de persecução aos crimes internacionais é identificado pelo conceito de implementação indireta (indirect enforcement), sendo este o que toca mais diretamente o tema deste trabalho.

Este sistema é caracterizado pelo exercício da persecução penal dos crimes internacionais próprios e/ou impróprios pelos Estados em regime de cooperação internacional em matéria penal. Conforme Bassiouni, ele é fundado sobre dois aspectos:

O primeiro aspecto é a assunção pelos Estados de incorporarem em seus ordenamentos jurídicos as obrigações decorrentes do [Direito Penal Internacional]. Este processo de internalização (domestication) do [Direito Penal Internacional] destina-se, em parte, a que as obrigações decorrentes dos tratados sejam reguladas segundo o direito nacional. Assim, a internalização do [Direito Penal Internacional] torna-o aplicável pelo sistema normativo nacional em conformidade com as suas exigências. O segundo aspecto deriva do primeiro, e consiste [em] que os Estados exerçam seus procedimentos legais não somente para executar as suas obrigações em nível interno (obligations domestically), mas também para cumprir suas obrigações de cooperar internacionalmente. A expressão "cooperação interestatal em matéria penal" aplica-se às modalidades invocadas pelos Estados em suas relações bilaterais para dar eficácia as suas respectivas normas penais (BASSIOUNI, 2013, p. 487).

O regime da implementação indireta, portanto, estriba-se por sobre dois fundamentos: a) a internalização das obrigações internacionais em matéria penal - convencionais ou consuetudinárias -, e que envolve, de um lado, na assunção de obrigações de prevenir e/ou exercer a persecução penal dos autores de crimes internacionais segundo os princípios jurídicos fundamentais dos Estados, com especial ênfase nos princípios da territorialidade e da jurisdição universal, e de outro, a depender dos termos em que vazados a fonte da obrigação 
internacional, na de tipificar internamente o comportamento, e b) a criação de obrigações internacionais que instituem princípios, procedimentos e formas de cooperação internacional em matéria de Direito Penal, tais como a extradição e a entrega de acusados ou condenados, a assistência legal, a execução de sentenças penais estrangeiras, a transferência internacional de processos, o bloqueio e repatriação de dinheiro e/ou bens objetos de crimes, a execução de regimes de inteligência e compartilhamento de informações e investigação conjunta etc.

Esse regime tem como princípio fundamental (cornerstone) a máxima processar ou extraditar (aut dedere aut judicare), frente à qual todos os demais institutos pertinentes à cooperação internacional em matéria penal são "secundários" ${ }^{19}$, na medida em que os diversos processos de incriminação pelo Direito Internacional se fundam sobre o interesse comum dos Estados de cooperarem na prevenção e na punição de crimes, em especial os internacionais, como, de resto, se evidencia pela Declaration of the High-level Meeting of the General Assembly on the Rule of Law at the National and International Levels, de 30 de novembro de 2012, da AGONU, que em seu item 22 reafirmou o comprometimento político dos Estados Membros em:

[...] garantir que não [será] tolerada a impunidade por genocídio, crimes de guerra e crimes contra a humanidade ou para as violações do Direito Internacional Humanitário e graves violações de direitos dos direitos humanos, e que tais violações sejam adequadamente investigadas e sancionadas de forma adequada, inclusive para se levar os autores de quaisquer crimes à justiça, através de mecanismos nacionais ou, se for

\footnotetext{
${ }^{19}$ Informa Donnedieu de Vabres que a fórmula latina foi cunhada no século 14 por Baldus, tendo origem em norma do Código de Justiano contida no Livro III, Título 15 - "Ubi de Criminibus Agi Oportet", e que foi posteriormente desenvolvida por Hugo Grotius em 1624 em seu 2o volume d'O Direito da Guerra e da Paz, vazada na díade "aut dedere... aut punire". No entanto, a partir da influência do liberalismo penal no século XVIII, a fórmula adquiriu a sua atual composição, "aut dedere aut judicare", ou "the obligation to extradite or prosecute": "Tel qu'on vient de le définir, le système de l'universalité du droit de punir a sa modeste origine dans un texte du Code de Justinien, C. III, 15, Ubi de criminibus agi oportet, 1, qui, déterminant le ressort, em matière pénale, des gouverneurs de l'Empire, donne à la fois compétence au tribunal du lieu de commission du délit, et à celui du lieu d'arrestation du coupable (judex deprehensionis) [...] II appartint à Grotius qui fut, à l'aube du xvii siècle, le grand vulgarisateur, sinon le fondateur du droit international, d'attacher à la théorie de la compétence universelle toute sa valeur philosophique. A l'heure où les grandes unités politiques, de constitution récente, se dressaient les unes contre les autres, il formula, comme un précurseur, la loi de la solidarité humaine. Il existe, dit-il, une société universelle des hommes, societas generis humani. Le crime, envisagé comme une violation du droit naturel qui la régit, droit non écrit, mais gravé dans la conscience individuelle, est une offense à I'humanité tout entière. L'obligation de punir qu'il engendre est universelle. Elle se traduit, pour l'Etat dans le pouvoir duquel le criminel est tombé, par l'alternative fameuse d'extrader ou de punir: aut dedere, aut punire. L'influence de Grotius peut s'observer dans la doctrine de ses successeurs hollandais, scandinaves ou allemands. On la rencontre au xviii siècle, et dans la période revolutionnaire, où la pure tendance individualiste et humanitaire résiste au socialisme, à l'étatisme issus du Contrat social. On la retrouve, au cours du xix siècle, dans les écrits de nombreux théoriciens, et dans quelques législations positives". (Apud BASSIOUNI, 2001, pp. 09-10; no mesmo sentido, BASSIOUNI, 2013, pp. 487-496).
} 
caso, mecanismos regionais ou internacionais, em conformidade com o Direito Internacional [...].

Portanto, a exata compreensão da máxima aut dedere aut judicare pressupõe, num primeiro momento, que se estabeleçam as diferentes formas pelas quais os Estados exercem as suas jurisdições penais, melhor compreendidas a partir da díade esfera de validade e esfera de eficácia ${ }^{20}$.

Todo Estado é, pois, um ente territorial, pois o território identifica e delimita o “[...] espaço no qual a ordem jurídica nacional se aplica [...] onde cada Estado exerce válida e permanentemente sua própria autoridade [...] sua própria competência" (ACCIOLY, 2009, p. 157). Isso implica em afirmar, doutro passo, que toda pessoa ou coisa que se encontre na esfera de validade do direito nacional, bem como qualquer violação ao direito que nele venha a ocorrer, torna, como regra geral, legítimo o exercício da persecução de imputação da responsabilidade decorrente da iliceidade cometida. A esse princípio fundamental denomina-se de princípio da territorialidade (ACCIOLY, 2009, p. 158), e que no Direito Penal brasileiro é regido pelas regras contidas no artigo 5을 $\mathrm{CP}^{21}$.

20 "As normas jurídicas internacionais regem o comportamento dos Estados e de outras pessoas internacionais, em qualquer parte onde as respectivas competências se possam exercer. Em relação a cada Estado, suas competências se estendem, normalmente, a certo espaço limitado, que é o território próprio, espaço onde sua autoridade é reconhecida pelo direito internacional geral e se exerce plena e validade. O domínio ou esfera de validade das competências do Estado ou da ordem jurídica estatal não se deve confundir [...] com a sua esfera de eficácia. O primeiro é aquele no qual o Estado executa, ou aplica, com exclusividade, suas próprias normas. A esfera de eficácia é mais extensa, sendo, por assim dizer, ilimitada" (ACCIOLY, 2009, p. 156).

21 "Dois aspectos sobressaem em relação à competência territorial do Estado em matéria penal. 0 primeiro deriva da cláusula de imunidade penal (artigo 7으, caput, parte final do CP) em razão das imunidades internacionais decorrentes das Convenção de Viena sobre Relações Diplomática, de 1961, Consulares, de 1963 [...] No entanto, é importante destacar que tais imunidades de jurisdição não podem ser vistas como fatores de impunidade. Com efeito, nos termos da CVRD/61, em seu artigo 31, 4, o Estado acreditante tem a obrigação de efetivar a persecução penal de seu representante que tenha cometido um ilícito penal no território do Estado acreditado. Segundo ponto a se destacar é o relativo à abrangência da expressão território para os termos do artigo 5o do CP. Com efeito, entende-se por território o conjunto de domínios (terrestre, marítimo, aéreo, fluvial etc) no qual o Estado exerce soberanamente a sua jurisdição de conformidade com o Direito Internacional. Em outros termos, o conceito de território não é geográfico, mas jurídico [...]. De outro giro, nos termos do artigo 5으, §1으, as embarcações e aeronaves de caráter público ou a serviço do Estado Brasileiro estão submetidas à sua jurisdição onde quer que estejam por serem consideradas extensões do território brasileiro. Já as embarcações e aeronaves privadas com pavilhão brasileiro sujeitam-se à competência penal brasileira quando o crime tenha sido praticado em alto-mar ou no espaço aéreo a ele correspondente. No que concerne, por fim, às embarcações e aeronaves privadas de pavilhão estrangeiro, conforme o prevê o $\S 2 \circ$, somente estarão sujeitas à jurisdição brasileira caso o ilícito penal tenha sido praticado quando elas se encontravam ou no espaço aéreo nacional ou aportadas em porto ou navegando no mar territorial brasileiro (nesse sentido, a hipótese não é a da extensão do §1으, mas de territorialidade em sentido estrito)." (DE OLIVEIRA, 2012, pp. 9-10). 
Já a esfera de eficácia identifica, noutro passo, a legitimidade de o Estado exercer suas jurisdições para perseguir a imposição de suas normas jurídicas por atos ou fatos que se tenham cometido fora de seu território, identificado pelo conceito de extraterritorialidade, e que no âmbito do Direito Penal brasileiro é regido pelas regras contidas no artigo 70 do $\mathrm{CP}^{22}$, tendo como paradigma jurisprudencial o caso Lotus, julgado em 07 de setembro de 1927 pela CPIJ ${ }^{23}$.

Os dois conceitos acima desenvolvidos são importantes na medida em que eles modulam, na forma de obrigações alternativas, o exercício da jurisdição penal em relação aos crimes internacionais a partir da máxima aut dedere aut judicare, que cria para os Estados os deveres de prevenir, geralmente mediante a existência de mandados de criminalização do comportamento, e exercer a persecução penal dos autores de crimes internacionais, quer eles tenham sido praticados em seus territórios ou fora dele, e de outro lado, caso não queiram ou

22 "Esta modalidade de competência penal tem duas fontes diversas de fixação: a) através da própria legislação penal do Estado, como é o caso do artigo 7o do CP. Trata-se, a rigor, de autoatribuição de competência, pela qual o Estado, no exercício de sua soberania legiferante fixa para si a competência persecutória em relação a determinados delitos; e b) pela assunção de obrigações internacionais de perseguir ilícitos especialmente graves para a Sociedade Internacional e que tenham sido praticados: i) por nacionais ou estrangeiros residentes do Estado em território de outro Estado ou em domínio internacional, e ii) por estrangeiros que tenham praticado delitos especialmente graves (crimes internacionais propriamente ditos) onde quer que tenham sido cometidos. Estas duas últimas hipóteses abarcam o conceito de jurisdição universal, um dos principais institutos do Direito Penal Internacional, funcionalmente destinado à persecução penal contra as grave violações aos Direitos Humanos [...]. São duas as hipóteses de extraterritorialidade previstas no artigo 70 do CP. A primeira, prevista no inciso I, trata da extraterritorialidade incondicionada, assim denominada em razão de o legislador brasileiro não prever qualquer condição prévia de caráter substancial (v.g., dupla tipicidade) ou de caráter fático (v.g., a entrada do autor do delito em território nacional) para que o Estado brasileiro possa iniciar a persecução penal. [...] A segunda hipótese de extraterritorialidade é a prevista no inciso II, denominada de extraterritorialidade condicionada. É condicionada porque a lei brasileira somente será aplicada se se concretizem as exigências estabelecidas nos $\S \S 20$ e 3으, a e b do artigo 7ㅇ․ Nestas hipóteses (crimes que, por tratado internacional o Estado brasileiro se tenha obrigado a reprimir, ou que tenham sido praticados por brasileiro no estrangeiro ou a bordo de aeronaves ou embarcações de pavilhão nacional de natureza privada em território estrangeiro, e que ali não tenham sido julgados, bem como por estrangeiro contra brasileiro no exterior), a jurisdição penal brasileira somente será exercida: a) se o agente ingressar no território nacional, b) ocorrer o fenômeno da dupla tipicidade, c) estar o crime incluído entre aqueles para o qual o ordenamento brasileiro admite extradição (cláusula de exclusão do artigo 5o, inciso LII da CRFB/88, a saber, a inextraditabilidade pela prática de crimes políticos ou de opinião) e d) a inocorrência de condenação e cumprimento de pena pelo crime que se pretende perseguir no estrangeiro, bem como não ter havido perdão ou extinção da punibilidade. Com relação à hipótese do §3o, se somam àquelas condições outras mais: a) que não tenha sido pedida ou que tenha sido negada extradição formulada pelo Governo Brasileiro e b) ter sido requisitado pelo Ministro da Justiça." (DE OLIVEIRA, 2012, pp. 14-15). ${ }^{23}$ A CPIJ, tendo como parâmetro os votos proferidos pelos Juízes Altamira e Huber, afirmou a legitimidade do exercício da jurisdição penal extraterritorial do Estado turco a partir do princípio geral de liberdade, também denominado de norma geral exclusiva, segundo o qual, ao Estado somente se objetaria a persecução caso houvesse uma norma de Direito Internacional que explicitamente o proibisse. (CPIJ, 1927). 
não possam exercê-la, extraditar o acusado para o Estado que se julgar competente para fazê-lo ou entregá-lo para um tribunal penal internacional (UN, CDI, 2014).

Assim, conforme Zdzislaw Galicki, em seu relatório preliminar sobre o tema, apresentado em 07 de junho de 2006 perante a CDI:

[Esta] obrigação é construída [como uma] alternativa, dando ao Estado a escolha para decidir que parte desta obrigação vai cumprir. Presume-se que após o cumprimento de uma parte dessa obrigação composta, o Estado é livre para cumprir a outra. Há a possibilidade, no entanto, [de] que um Estado deseje cumprir ambas as partes da obrigação em questão. Por exemplo, após o estabelecimento de sua jurisdição, [do exercício] da persecução, do julgamento e condenação de um criminoso, o Estado pode decidir extraditar o ofensor para outro Estado, [que] também [tem] o direito de estabelecer a sua jurisdição, com a finalidade de executar a sentença [...] (UN, CDI, 2006).

Referida caracterização foi confirmada no Relatório Final da CDI, no qual se consignou que a máxima aut dedere aut judicare cria as seguintes obrigações internacionais para os Estados: a) as normas internacionais impõem aos Estados a obrigação de exercer a persecução penal quando, tendo sido solicitada a extradição do acusado, ela não foi concedida em razão, v.g., de alguma proibição decorrente de seu ordenamento jurídico, ou, num segundo nível, uma obrigação ipso facto de processar o infrator que se encontre em seu território. Em ambas as hipóteses "[...] o Estado é obrigado a processar o indivíduo", e b) derivada, pois, dessas duas obrigações, surge para o Estado a alternativa de extraditar ou julgar somente quando, concretamente, referidos pedidos forem feitos, podendo o Estado optar entre o exercício da persecução penal ou pela extradição/entrega do indivíduo. Em qualquer circunstância, o descumprimento de tais deveres implica na imputação de responsabilidade internacional ao Estado, não se constituindo, pois, numa faculdade que possa ser ilida por qualquer argumento de ordem jurídica ou política (UN, CDI, 2014).

A finalidade, portanto, da regra processar ou extraditar é, de um lado, suprir a lacuna da punibilidade fática que favoreça aos autores de crimes internacionais, pois, a partir desse genuíno princípio fundamental do Direito Penal Internacional, quer o Estado territorialmente competente exerça ou não a sua jurisdição penal, nada obsta que outro Estado o faça, e em sede de crimes internacionais próprios, surge a possibilidade do exercício da persecução penal por um Tribunal Penal Internacional através da denominada "terceira alternativa" 24 , e de outro

24 "With the establishment of the International Criminal Court and various ad hoc international criminal tribunals, there is now the possibility that the State faced with na obligation to extradite or prosecute na accused person might have recourse to a third alternative - that a surrendering the suspect to a competente international criminal tribunal. This third alternative is stipulated, for exemple, in article 11, 
lado, instituir procedimentos, princípios e regimes de cooperação internacional entre os Estados ou entre estes e os tribunais penais internacionais, em especial a extradição ou a entrega, preservando, embora de forma mitigada, as jurisdições penais dos Estados.

Esta asserção é comprovada, noutro passo, pelo fato de inúmeros tratados internacionais em matéria penal preverem referido princípio, sendo que a CDI em seu Relatório Final reconhece a sua validade internacional somente na forma de norma convencional; no que concerne, doutro passo, a uma pressuposta natureza costumeira, por existir um enorme dissenso entre os Estados, mormente após decisão da CIJ no caso Bélgica vs. Senegal ${ }^{25}$, em que ela indeferiu o pedido feito pela Bélgica de se determinar a obrigação de extraditar sob o argumento de que referido princípio somente seria exigível para fatos ocorridos após a ratificação por Senegal da Convenção contra a Tortura, nos termo do artigo 28 da Convenção de Viena sobre o Direito dos Tratados entre Estados (CIJ, 2012, p. 39), a CDI não logrou consignar a existência dos elementos constitutivos do costume internacional, em especial a opinio iuris sive necessitatis.

A regra da extraditabilidade dos crimes internacionais é internacionalmente assegurada por duas cláusulas comuns a muitos tratados internacionais sobre a matéria. A primeira delas é conformada pela inexigibilidade de existência de um tratado internacional de extradição entre os Estados ativo e passivo, bastando, portanto, ou a promessa de reciprocidade pelo Estado solicitante ou que o Estado passivo considere o próprio tratado internacional como fundamento para a concessão da extradição, desde que referida medida seja compatível com o direito interno. De outro lado, a extraditabilidade é assegurada por meio da cláusula comum a muitos

paragraph 1 of the International Convention for the Protection of All Persons from Enforced Disappearance, 2006". (UN, CDI, 2014, p. 11).

${ }^{25} \mathrm{~A}$ CIJ, nessa demanda que tinha por direito aplicável disposições da Convenção contra a Tortura, consignou a natureza cogente desse princípio na forma de uma obrigação erga omnes seguindo, pois, a sua própria jurisprudência, mormente o Parecer Consultivo sobre Reservas à Convenção sobre Genocídio, nos seguintes termos: "[...] The States parties to the Convention have a common interest to ensure, in view of their shared values, that acts of torture are prevented and that, if they occur, their authors do not enjoy impunity. The obligations of a State party to conduct a preliminary inquiry into the facts and to submit the case to its competent authorities for prosecution are triggered by the presence of the alleged offender in its territory, regardless of the nationality of the offender or the victims, or of the place where the alleged offences occurred. All the other States parties have a common interest in compliance with these obligations by the State in whose territory the alleged offender is present. That common interest implies that the obligations in question are owed by any State party to all the other States parties to the Convention. All the States parties "have a legal interest" in the protection of the rights involved (Barcelona Traction, Light and Power Company, Limited (Belgium v. Spain), Second Phase, Judgment, I.C.J. Reports 1970, p. 32, para. 33). These obligations may be defined as "obligations erga omnes partes" in the sense that each State party has an interest in compliance with them in any given case. In this respect, the relevant provisions of the Convention against Torture are similar to those of the Convention on the Prevention and Punishment of the Crime of Genocide" (CIJ, 2012, p. 31). 
tratados internacionais sobre a matéria, segundo a qual o crime internacional regulado não poderá ser considerado como crime político, de modo que, de um lado, se impeça a concessão de asilo político ou o refúgio, e de outro lado obriga o Estado, ante sua omissão em processar e julgar o acusado, de extradita-lo ou entrega-lo para o Estado ou o Tribunal Penal Internacional solicitante.

Por seu passo, o princípio da justiça universal, também denominada justiça cosmopolita, se manifesta como uma decorrência da máxima processar ou extraditar. Por ela, os Estados detêm legitimidade internacional para exercer a persecução penal dos autores de crimes internacionais na forma da jurisdição penal extraterritorial, isto é, para fatos que se tenham cometido fora de sua esfera de validade, se constituindo, a todo rigor, num dos temas mais polêmicos hoje existentes no âmbito do Direito Penal Internacional. Conforme afirmado por Bassiouni,

A jurisdição universal tornou-se a técnica preferida por aqueles que procuram evitar a impunidade dos crimes internacionais. Não havendo dúvidas de que é um instrumento útil e, por vezes, a técnica necessária, [ela] também tem aspectos negativos. O exercício da jurisdição universal é geralmente reservado para os mais graves crimes internacionais, tais como crimes de guerra, crimes contra a humanidade e genocídio. Entretanto, podem existir outros crimes internacionais nos quais um tratado aplicável prevê referido fundamento jurisdicional, como no caso do terrorismo. [O exercício] desenfreado da jurisdição universal pode causar perturbações na ordem mundial e [a] privação de direitos humanos individuais quando utilizada de forma politicamente motivada ou para fins abusivos. Mesmo com a melhor das intenções, a jurisdição universal pode ser usada imprudentemente, criando atritos desnecessários entre os Estados [...].

A jurisdição universal deve, portanto, ser utilizada de forma cautelosa [par]a minimiza[r] possíveis consequências negativas, de modo a permitir que atinja as suas finalidades [...] Além disso, deve-se notar que o Direito Internacional Privado ainda não tem regras ou critérios desenvolvidos suficiente[mente] claros para estabelecer prioridades no exercício da jurisdição penal [para quando ocorrer] a reivindicação de mais de uma jurisdição estatal (BASSIOUNI, 2001, p. 3).

Essa modalidade de jurisdição penal extraterritorial tem como regra de conexão a incriminação internacional, ou como prefere Bassiouni, a natureza (internacional) do crime aliada à finalidade da sociedade internacional em perseguir a imputação da responsabilidade penal (BASSIOUNI, 2001, p. 5), tendo por fundamento jurídico-político o conceito de actio popularis, pois o

[...] Estado age em nome da comunidade internacional porque tem interesse na preservação da ordem mundial como membro dessa 
comunidade [...] Como actio popularis, a jurisdição universal pode ser exercida pelo Estado sem que haja qualquer regra de conexão jurisdicional [without any jurisdictional connection or link] entre o local da comissão, a nacionalidade do acusado, a nacionalidade da vítima e o Estado competente [enforcing state]. O fundamento é, portanto, exclusivamente a natureza do crime, e a finalidade é exclusivamente reforçar a ordem mundial para assegurar a [atribuição de] responsabilidade [ensuring accountability] pela prática de determinados crimes (BASSIOUNI, 2001, p. 5).

Outra não é a lição de Comellas Aguirrezábal, para quem

[...] el principio de jurisdicción universal, también llamado de universalidad o de justicia universal, es un título o criterio de atribución de jurisdicción cuya característica esencial estribaría en su falta de vinculación con los tradicionales elementos constitutivos del Estado: ni se vincula al territorio (base natural que habilita el ejercicio de la función jurisdiccional y que, junto a razones de índole práctica, determinan que la regla general en el ámbito penal sea el principio de territorialidad), ni con la población (con la que están relacionados los principios de nacionalidad o personalidad activa y pasiva), ni con la organización del poder (a la que está de alguna manera ligado el principio real o de protección de intereses). Diferenciándolo, por tanto, de otros criterios de atribución de jurisdicción, el principio de universalidad se concebiría como un título en virtud del cual los Estados asumen competencia para perseguir y enjuiciar delitos cometidos en el extranjero, por extranjeros, contra extranjeros y sin que tal Estado pueda considerarse especialmente lesionado (COMELLAS AGUIRREZÁBAL, 2010, p. 67).

Esta ideia central de que a jurisdição universal enseja, pelo só fato da incriminação internacional, aliada ao conceito de actio popularis, o exercício da persecução penal sem que haja qualquer vínculo entre o Estado que a exerce e o fato ou o seu autor, tem suscitado não poucas polêmicas no contexto da sociedade internacional contemporânea, mormente porque, como dito por Bassiouni, o uso desarrazoado, embora bem intencionado por parte de juízes nacionais, tem sido causa frequente de conflitos diplomáticos entre os Estados envolvidos e de violação a princípios e regras fundamentais da sociedade internacional.

Conforme indica Cassese, existem duas teorias acerca da extensão do princípio da jurisdição universal. A primeira ele denomina de "absoluta", a segundo de "condicionada" (CASSESE, 2004, p. 67).

A teoria da justiça universal absoluta, muitas vezes identificada com a defenestração feita por Beccaria contra a regra aut dedere aut judicare em seu Dos Delitos e das Penas ${ }^{26}$, e

\footnotetext{
26 "Alcuni credono parimente che un'azione crudele fatta, per esempio, a Costantinopoli possa esse punita a Parigi, per l'astratta ragione che chi ofende l'umantà (sic) merita di avere tutta l'umanità inimica, e l'esecrazione universale; quase che i giudici vindici fossero della sensibilità degli uomini, e non piuttosto dei patti che li legano fra di loro" (BACCARIA, V. 1, 1958, p. 95, grifamos). A expressão "quase che si giudici vindici fossero della sensibilità degli uomini" tem sido geralmente traduzida pela expressão "como
} 
que conta, em nível doutrinário, com a adesão de inúmeros internacional-penalistas e, em parte, no The Princeton Principles on Universal Jurisdiction de $2001^{27}$, e em nível legislativo nas regulamentações nacionais inicialmente previstas no art. 23.4 da Lei Orgânica do Poder Judiciário, da Espanha, e na Bélgica através da Lei Relativa à Repressão das Graves Violações do Direito Internacional Humanitário, de 1993, sustenta a ideia de que esse

[...] sistema consiste em autorizar as jurisdições nacionais a se pronunciarem sobre processos penais movidos contra qualquer pessoa acusada de graves crimes internacionais, sem, no entanto, exigir previamente que esta se encontre, mesmo que de passagem, em seu território. Portanto, mesmo na ausência do autor presumido do crime internacional, o juiz nacional pode mover processos penais, instaurar inquérito, buscar os elementos de prova necessários, e até mesmo expedir mandado de prisão [...] os juízes podem julgar ações penais contra qualquer chefe de Estado ou órgão do Estado estrangeiro, desde que alguém apresente queixa. (CASSESE, 2004, p. 16).

Para Jankov, que afirma a validade dessa modalidade absoluta:

[...] a jurisdição universal, ou melhor denominado, princípio da jurisdição universal, configura-se como a possibilidade de o Estado exercer a jurisdição prescritiva na ausência de qualquer outro vínculo jurisdicional aceitável na época da ocorrência do crime [...] de acordo com o princípio [...] um Estado afirma sua competência sem que exista qualquer critério de conexão direto com a infração, inclusive sem ser necessária a presença do autor em seu território (JANKOV, 2009, p. 105).

se os juízes fossem cavaleiros errantes da natureza humana" nos parece, para além de qualquer dúvida razoável, num claro erro de tradução (CASSESE, 2004, p. 17).

27 "Principle 1 - Fundamentals of Universal Jurisdiction: 1. For purposes of these Principles, universal jurisdiction is criminal jurisdiction based solely on the nature of the crime, without regard to where the crime was committed, the nationality of the alleged or convicted perpetrator, the nationality of the victim, or any other connection to the state exercising such jurisdiction. 2. Universal jurisdiction may be exercised by a competent and ordinary judicial body of any state in order to try a person duly accused of committing serious crimes under international law as specified in Principle 2(1), provided the person is presente before such judicial body. 3. A state may rely on universal jurisdiction as a basis for seeking the extradition of a person accused or convicted of committing a serious crime under international law as specified in Principle 2(1), provided that it has established a prima facie case of the person's guilt and that the person sought to be extradited will be tried or the punishment carried out in accordance with international norms and standards on the protection of human rights in the context of criminal proceedings. 4. In exercising universal jurisdiction or in relying upon universal jurisdiction as a basis for seeking extradition, a state and its judicial organs shall observe international due process norms including but not limited to those involving the rights of the accused and victims, the fairness of the proceedings, and the independence and impartiality of the judiciary (hereinafter referred to as "international due process norms"). 5. A state shall exercise universal jurisdiction in good faith and in accordance with its rights and obligations under international law." PRINCETON UNIVERSITY. The Princeton Principles on Universal Jurisdiction, disponível em https://lapa.princeton.edu/hosteddocs/unive_jur.pdf, acessado em 20.OUT.2011, às 14:00. 
Já a teoria da jurisdição universal condicionada, defendida por Cassese, sustenta a necessidade de que essa forma de jurisdição penal extraterritorial seja exercida "cum grano salis", e desde que satisfeitas determinadas exigências, em particular que:

[...] o indiciado encontre-se no território do foro [...], pois exige sempre a presença do autor presumido do crime no território do juiz, como condição essencial à qual fica subordinada a própria existência da jurisdição", fundando-se, nesse sentido, no princípio do forum deprehensionis nos termos do adágio "ubi te invenero, ibi te judicabo" (CASSESE, 2004, p. 16).

Em outras palavras, não caberia aos tribunais nacionais agirem como se fossem "[...] vindici [...] della sensibilità degli uomini [...]", mas como substitutos às "[...] jurisdições nacionais omissas para garantir em seu lugar que a justiça seja feita. Esses juízes nacionais ficariam incumbidos de agir como órgãos da comunidade internacional, como guardiões dos valores fundamentais dessa comunidade" (CASSESE, 2004, pp. 16-18).

Para Cassese, esta compreensão relativizada da jurisdição universal evitaria alguns problemas especialmente graves em termos de eficácia e eficiência, e que cobram um preço considerável para a própria legitimidade interna e internacional do instituto, a saber: a) o primeiro atine à circunstância de que é possível que o acusado não se apresente perante o juízo nacional - por ingresso espontâneo no território, pela denegação de pedido extradicional, pelo não cumprimento do mandado de prisão internacional etc -, impossibilitando, nesse sentido, o seu efetivo julgamento; b) caso o juízo resolva julgar o acusado à revelia (in absentia), referida medida violaria um conjunto de direitos humanos que asseguram um julgamento justo, atraindo, de um lado, a impossibilidade de cumprimento do mandado de execução da pena por sua manifesta nulidade, e de outro suscitar críticas a tais violações, cobrando seríssimo preço em termos de legitimidade do procedimento; c) a abertura de processo em tais casos, mormente se envolver (ex-)Chefes de Estado ou Órgãos Superiores de outro Estado, ilidirá a colheita de provas caso o Estado do "loci delict comissi" decida não cooperar, impossibilitando também a eficiência da instrução processual; e d) se todos os Estados adotarem o modelo absoluto, e ante a ausência já indicada por Bassiouni de uma regra internacional para a solução de conflitos jurisdicionais sobre a matéria, elevaria o risco de apreciações divergentes, com a possibilidade de decisões judiciais excludentes entre si e ofensa à garantia ao ne bis in idem (CASSESE, 2004, p. 17).

Em duas ocasiões em que a $\mathrm{ClJ}$ foi provocada a se manifestar sobre conflitos decorrentes do exercício da jurisdição universal absoluta, tal como prevista na legislação belga, 
ela considerou-a incompatível em face de diversos princípios fundamentais do Direito Internacional

No caso Mandado de Prisão de 11 de Abril de 2000, também denominado Yerodia, envolvendo a República Democrática do Congo vs o Reino da Bélgica (CIJ, 2000), versa sobre o conflito decorrente da emissão de mandado de prisão internacional in absentia por um magistrado belga em face do então Ministro das Relações Exteriores do Congo, Abdoulaye Yerodia Ndombasi, em que se lhe imputava a prática do crime de incitação ao genocídio de forma pública e ostensiva contra a minoria tutsi no curso dos conflitos étnicos ocorridos em 1998 no país. O Congo, ao propor a reclamação internacional, infirmou a legitimidade do procedimento penal a partir de dois fundamentos: a) a Bélgica violara a regra consuetudinária de imunidade internacional, inclusive penal, de que são revestidos Chefes de Estado e Ministros das Relações Diplomáticas e b) a violação ao princípio da igualdade soberana entre os Estados, pelo qual um Estado não está submetido à autoridade do outro. A Bélgica, em sua defesa, alegou a legitimidade do exercício da persecução penal na forma da justiça universal tal como prevista em seu ordenamento jurídico, na medida em que o caso fora aberto sem que o acusado estivesse em seu território ou presentes quaisquer elementos de conexão - e.g. vítimas ou acusados de nacionalidade belga ou qualquer reflexo de tais comportamentos em seu território -. Em outros termos, bastava a presença do elemento de conexão da incriminação internacional do comportamento.

A Corte, no julgamento de mérito, considerou, por maioria, que a expedição do mandado de prisão internacional violara tanto a imunidade internacional dos Ministros de Relações Diplomáticas ${ }^{28}$, como a necessidade de que a Bélgica, para poder exercer a jurisdição universal em face de crimes internacionais, comprovasse a presença de elementos mínimos de conexão entre o fato e o seu interesse na persecução penal, sob pena de se convalidar a violação ao princípio da não intervenção em assuntos de jurisdição interna ${ }^{29}$.

28 "The Court accordingly concludes that the functions of a Minister for Foreign Affairs are such that, throughout the duration of his or her office, he or she when abroad enjoys full immunity from criminal jurisdiction and inviolability. That immunity and that inviolability protect the individual concerned against any act of authority of another State which would hinder him or her in the performance of his or her duties." (CIJ, 2000, p. 6).

29 "The universal jurisdiction that the Belgian State attributes to itself under Article 7 of the Law in question contravenes the international jurisprudence established by the Judgment of the Permanent Court of International Justice (PCIJ) in the "Lotus" case (7 September 1927, Judgment No. 9, 1927, P.C.I.J., Series $A$, No. 10). The Court recognized at that time that territoriality is a principle of international law (while ruling that this principle is not absolute, in that it cannot prevent a State from prosecuting acts done outside its territory if they had consequences on that territory, such as, in that case, on board a ship 
Os Juízes Guillaume, Rezek e Rajeva, em seus votos em separado, apresentaram importante distinção no concernente às formas de manifestação do princípio da justiça universal. A primeira seria aquela que poderia ser exercida, independentemente da presença do acusado no foro, por eles denominada de universal criminal jurisdiction properly so called, e a segunda denominada de territorial jurisdiction over persons for extraterritorial events, e que exige a presença do acusado perante o juízo processante. Para estes juízes, a jurisdição universal em sentido estrito somente poderia ser exercida desde que preenchidas as seguintes condições: a) que o Estado, antes de iniciar a persecução penal, oportunizasse ao Estado territorialmente competente pronunciar-se sobre os fatos; b) que os órgãos investidos de competência persecutória e judicial gozem das prerrogativas de independência funcional; c) que a persecução penal seja iniciada a partir do pedido formulado ou pelas vítimas ou por seus familiares; d) que os fatos se subsumam entre as hipóteses de core crimes; e) que sejam respeitadas as regras e princípios internacionais que orientam as relações entre Estados, em especial as imunidades internacionais (CASSESE, 2004, p. 18).

A segunda decisão da CIJ, também envolvendo a legislação belga sobre crimes internacionais próprios - Bélgica vs. Senegal (CIJ, 2012) -, a Corte cindiu a análise do caso em dois pontos distintos tendo como base a regra aut dedere aut judicare: a) o Senegal tinha a obrigação internacional de exercer a persecução penal em face de Hissène Habré, porquanto a incriminação do crime de tortura se constitui em uma obrigação erga omnes e de natureza jus cogens derivada não da Convenção contra a Tortura, mas do direito internacional costumeiro ${ }^{30}$, não sendo admissível, internacionalmente, que o autor de tais atos - ex-Presidente do Chade -, ficasse impune em razão de asilo diplomático a ele concedido; b) no que concerne, doutro

flying the Turkish flag). According to the judgment, this principle means that a State may not exercise its authority on the territory of another State. This rule of jurisprudence is now corroborated by Article 2, paragraph 1, of the Charter of the United Nations, which states: "The Organization is based on the principle of the sovereign equality of all its Members." The only instances in which general international law allows, exceptionally, that a State may prosecute acts committed on the territory of another State by a foreigner are, first, cases involving violation of the security or dignity of the first State and, second, cases involving serious offences committed against its nationals." (CIJ, 2000, p. 15).

30 "In the Court's opinion, the prohibition of torture is part of customary international law and it has become a peremptory norm (jus cogens). That prohibition is grounded in a widespread international practice

and on the opinio juris of States. It appears in numerous international instruments of universal application (in particular the Universal Declaration of Human Rights of 1948, the 1949 Geneva Conventions for the protection of war victims; the International Covenant on Civil and Political Rights of 1966; General Assembly resolution 3452/30 of 9 December 1975 on the Protection of All Persons from Being Subjected to Torture and Other Cruel, Inhuman or Degrading Treatment or Punishment), and it has been introduced into the domestic law of almost all States; finally, acts of torture are regularly denounced within national and international fora." (CIJ, 2012, p. 39). 
passo, à natureza convencional da regra processar ou extraditar, ela não poderia ser exigível do Senegal pela Bélgica em razão do princípio da irretroatividade contida no artigo 28 da CVDTE $/ 69^{31}$.

A consequência de referida decisão da $\mathrm{ClJ}$ foi a constituição de um tribunal internacional misto - a Câmaras Extraordinárias Africanas - por acordo entre o Senegal e a União Africana, para levar Hissène Habre a julgamento pelos crimes que se lhe imputam, e cujo resultado foi a sua condenação à pena de prisão perpétua.

\section{CONCLUSÕES}

Destarte, seria possível concluir-se que a tese afirmada por Cassese é a que melhor atende aos princípios do Direito Internacional, na de medida em que o princípio da jurisdição universal não foi instituído, apesar de ardorosos defensores em sentido contrário, para permitir que os Estados, sob as vestes de combate à impunidade, se imiscuam em assuntos de jurisdição interna de outros Estados, elevando, tanto em nível interno como internacional, a conflituosidade e o fechamento de alternativas civilizacionais de proteção aos direitos internacionalmente protegidos.

Doutro passo, é bastante evidente do relato acima exposto que o Direito Penal Internacional, tendo por pedra fundamental de sua conformação institucional o princípio aut dedere aut judicare, somente logrará, de fato, efetividade, se os Estados atenderem ao chamado internacional pela colmatação da impunidade fática dos crimes internacionais e realizarem, na facticidade histórica, a persecução dos autores dos crimes internacionais através do exercício, quando cabível, da actio popularis.

Se uma democracia consolidada exige, como condição de sua existência, que o cidadão assuma uma postura ativa e institucionalmente adequada para a proteção dos interesses coletivos, o mesmo se dá no plano internacional, uma vez que a realização histórica da rule of law impõe comportamentos políticos que transcendem a mera proteção dos interesses particulares do Estado a fim de que se processe concretamente a defesa comum e também institucionalmente adequada dos interesses e valores comuns da sociedade internacional.

31 "However, the obligation to prosecute the alleged perpetrators of acts of torture under the Convention applies only to facts having occurred after its entry into force for the State concerned. Article 28 of the Vienna Convention on the Law of Treaties, which reflects customary law on the matter [...]". (CIJ, 2012, p. 39). 
Em ambas as esferas, lembrando a máxima que deu origem à actio popularis - qui tam actio -, só há efetiva proteção de referidos valores e interesses - passíveis de serem sintetizados no princípio fundante e conformador da dignidade da pessoa humana -, se houver corresponsabilidade na prevenção geral e/ou especial de comportamentos institucionais e individuais que os violem, donde, por conseguinte, a colegitimidade de todos os Estado em cooperarem na persecução penal, seja por meio da persecução ativa, seja na cooperação internacional por intermédio, e.g., da extradição e da não concessão de asilo político a indivíduos que sejam acusados da prática dos crimes mais graves perante a sociedade internacional.

Contudo, essa colegitimidade e corresponsabilidade deve ser efetuada cum granus salis, vez que nem os juízes nacionais devam agir como se fossem "[...] vindici [...] della sensibilità degli uomini [...]", nem os Estados como se fossem xerifes da sociedade internacionais, utilizando-se dos institutos que o Direito Penal Internacional dispôs para a tutela daqueles valores e interesses comuns como meio à satisfação de seus interesses particulares ou para a promoção de suas geopolíticas.

Em síntese, é certo que a actio popularis constitui-se em um instituto vigente e legítimo no Direito Internacional contemporâneo, dando azo àquelas corresponsabilidade e colegitimidades tão caras ao aperfeiçoamento das insuficiências institucionais da sociedade internacional.

\section{REFERÊNCIAS}

ACCIOLY, Hildebrando. Tratado de Direito Internacional Público, 3 v., V. 2, 3 eds., São Paulo: Quartier Latin, 2009.

AMBOS, Kai. Impunidade por Violação dos Direitos Humanos e o Direito Penal Internacional, trd. Alexandra Rosado, Revista Brasileira de Ciências Criminais, ano 12, no 49, São Paulo: RT, 2004, pp. 48-88.

A Parte Geral do Direito Penal Internacional: bases para uma Elaboração Dogmática, trd. Carlos E. A. Japiassú e Daniel Andrés Raizman, São Paulo: RT, 2008.

BAZELAIRE, Paul, CRETIN, Thierry. A Justiça Penal Internacional: sua Evolução, seu Futuro de Nuremberg a Haia, trd. Luciana Pinto Venâncio, Barueri: Manole, 2004.

BASSIOUNI, M. Cherif. Universal Jurisdiction for International Crimes: Historical Perspectives and Contemporary Practice, Virginia Journal of International Law, no 42, v. 81, fall 2001.

The Perennial Conflict Between International Criminal Justice and Realpolitik, $38^{\text {th }}$ Henry J. Miller Distinguished Lecture, Georgia State University College of Law, disponível em 
http://law.gsu.edu/Miller_Lecture/2006/MillerLecture-S06-BassiouniDraft.pdf, acesso em: 15 mai. 2012.

Introduction to International Criminal Law: second revised edition, Leiden: Martinus Nijhoff Publishers, 2013.

BECCARIA, Cesare. Opere, 2 v., V. 1, Firenze: Sansoni, 1958.

BERGER, Adolf. Encyclopedic Dictionary of Roman Law, Philadelphia: The American Philosophical Society, 1953.

CASSESE, Antonio. Existe um Conflito Insuperável entre Soberania dos Estados e Justiça Penal Internacional?, in CASSESE, Antonio, DELMAS-MARTY, Mireille (Orgs). Crimes Internacionais e Jurisdições Internacionais, trd. Silvio Antunha, Barueri: Manole, 2004.

COMELLAS AGUIRREZÁBAL, Maria Teresa. La Jurisdicción Universal en España tras la Reforma de 2009: Racionalización del Principio o un Paso Atrás en la Lucha Contra la Impunidad?, Anuário Español de Derecho Internacional, vol 26, 2010.

COSTI, Alberto. Hybrid Tribunals as a Valid Alternative to International Tribunals for the Prosecution of International Crimes, Human Rights Research Review, vol 3, 2005, pp. 1-26, disponível em http://www.victoria.ac.nz/law/centres/nzcpl/publications/human-rightsresearch-journal/publications/vol-3/Costi.pdf, acessado em 20/03/2015, às 16:00.

DE OLIVEIRA, Marcus Vinícius Xavier. Da Inconstitucionalidade dos Artigos 7ㅇ, $\$ 10$ e 8 을 do Código Penal por Violação ao Princípio Ne Bis In Idem, Revista Quaestio luris, Rio de Janeiro, 2012, pp. 1-31.

Extensão e Fragmentação no Contexto da Jurisdição Penal Internacional, Revista de Direito Internacional, Vol. 13, № 3, 2016, pp. 423-443.

FAGUNDES, M. Seabra. Da Ação Popular, Revista de Direito Administrativo, Rio de Janeiro: Fundação Getúlio Vargas, 1946, pp. 1-19.

FELLMETH, Aron X., HORWITZ, Maurice. Guide to Latin in International Law, Oxford: New York: Oxford University Press, 2009.

FERREIRA DE ALMEIDA, Francisco António de M. L. Os Crimes Contra a Humanidade no Actual Direito Internacional Penal, Coimbra: Almedina, 2009.

INSTITUTO DEL TERCER MUNDO. Enciclopédia do Mundo Contemporâneo, São Paulo: Publifolha/Rio de Janeiro: Editora Terceiro Milênio, 2002.

JANKOV, Fernanda F. F. Direito Internacional Penal: Mecanismos de Implementação do Tribunal Penal Internacional, São Paulo: Saraiva, 2009.

JAPIASSÚ, Carlos Eduardo Adriano. O Tribunal Penal Internacional: a Internacionalização do Direito Penal, Rio de Janeiro: Lumen Juris, 2004. 
JOSÉ BREMER, Juano De Westfalia a post-Westfalia: Hacia un Nuevo Orden Internacional, Cuidad de México: Universidad Nacional Autonoma de México/Instituto de Investigaciones Jurídicas, 2013.

KLEINEN, Thomas. Konstitutionalisierung im Völkerrecht: Einer Idealistichen Völkerrechtslehre, Heildeberg: Springer, 2012.

LYNDEL, V. Prott. Some aspects of Judicial Reasoning in the South-West Africa Case of 1962, Belgian Review of International Law, 1967, Vol. 1, pp. 37-51.

MACEDO, Paulo Emílio Vauthier Borges de. Clóvis Beviláqua e a justiça internacional: entre o sim e o não a Rui Barbosa, Revista de Direito Internacional, v. 13, no 2, 2016, pp. 423-443.

MACKEAN, W. A. The South West Africa C:ases (1966): Two Views - I. "Legal right or interest" in the South West Africa Cases: a Critical Comment, Australian Year Book of International Law, 1966, V. 12, pp. 135-141.

The South West Africa C:ases (1966): Two Views - II. An Examination of Certain Criticisms of the South West, Africa Cases Judgment, Australian Year Book of International Law, 1966, V.12, pp. 143-148.

MOMMSEN, Theodor. Gesammelte Schriften: Juristischen Schriften, 3 v. V. 3, Berlin: Weidmannsche Buchhanlung, 1907.

Römisches Strafrecht, Leipzig: Verlag von Duncker \& Humblot, 1899.

PASTOR RIDRUEJO, José Antonio. Curso de Derecho Internacional Público y Organizaciones Internacionales, 18 ed., Madri: Tecnos, 2014.

PRINCETON UNIVERSITY. The Princeton Principles on Universal Jurisdiction, disponível em https://lapa.princetonoedu/hosteddocs/unive_jur.pdf, acessado em 20/10/2011, às 14:00.

ROSENNE, Shabtai. The Perplexities of Modern International Law, Leiden: Martinus Nijhoff Publishers, 2004.

RUBIN, Alfred P. Actio popularis, Jus Cogens and Offenses Erga Omnes?, New England Law Review, vol 35, no 2, 2000/2001, pp. 265-280.

SHAW, Malcolm. International Law, $6^{\text {th }}$ ed., Cambridge: Cambridge University Press, 2008.

SCHWELB, Egono The Actio Popularis and International Law, Israel Yarbook on Human Rights, v. 2, 1972, pp. 46-56.

TOMUSCHAT, Christiano Obligations Arising for States Without or Against Their Will, RCADI 241, 1993.

UNITED NATIONS. GENERAL ASSEMBLY. Declaration of the High-level Meeting of the General Assembly on the Rule of Law at the National and International Levels, 30 November 2012, disponível em http://www.unrol.org/article.aspx?article_id=192, acessado em 20.FEV.2014, às 20:00. 
GENERAL ASSEMBLY. Formulation of the Principles Recognized in the Charter of the Nümberg Tribunal and the Judgment of the Tribunal, 21 NOV 1947. Disponivel em http://daccess-dds-

ny.un-org/doc/RESOLUTION/GEN/NRO/038/84/IMG/NR003884.pdf?OpenElement, acessado em 20.FEV.2012, às 14:30.

GENERAL ASSEMBLY. Principles of International Law Recognized in the Charter of the Nürnberg Tribunal and in the Judgment of the Tribunal, 11 DEC 1946. Disponível em http://www.un-documents.net/a1r95.htm, acessado em 20.FEV.2012, às 14:00.

INTERNACIONAL LAW COMISSIONo The Obligation to Extradite or Prosecute (Aut Dedere Aut Judicare), Preliminary report, by Mr. Zdzislaw Galicki, Special Rapporteur, disponível em http://legal.unoorg/ilc/documentation/english/a_cn4_571.pdf, acessado em 20.SET.2014, às 14:50.

INTERNACIONAL LAW COMISSIONo The Obligation to Extradite or Prosecute (Aut Dedere Aut Judicare), Final Report of the International Law Commission 2014, disponível em http://legal.unoorg/ilc/texts/instruments/english/reports/7_6_2014.pdf, acessado em 20.SET.2014, às 18:00.

INTERNATIONAL LAW COMISSIONN Yearbook of the International Law Comission, vol II, 1950, pp. 374-378, disponivel em http://legal.unoorg/ilc/publications/yearbooks/english/ilc_1950_v2.pdf, acessado em 20.FEV.2012, às 13:35.

WEIL, Prosper. Le Droit International En Quête de Son Identité, RCAD vol. 237, 1992.

WERLE, Gerhard. Principles of International Criminal Law, $2^{\text {th }}$ ed., Hague: T.M.C. Asser Press, 2009.

Decisões Judiciais

PERMANENT COURT OF INTERNACIONAL JUSTICE. The case of S. S. Lotus, Série A, no 10, de September 7th, 1927, disponivel em http://www.icjcij.org/pcij/serie_A/A_10/30_Lotus_Arret.pdf, acessado em 30.JANo2009, às 21:00.

INTERNACIONAL COURT OF JUSTICE. International Status of South-West Africa. Advisory Opinion of July $11^{\text {th }}, 1950$, acessad em http://www.icj-cij.org/files/case-related/10/010-19500711-ADV01-00-ENopdf, acessado em 12.DEZ.2016, às 23:00

South West Africa Cases (Ethiopia v. South Africa; Liberia v. South Africa). Preliminary Objetctions. Judgment of 21 December 1962, disponivel em http://www.icj-cij.org/files/caserelated/47/047-19621221-JUD-01-00-ENopdf, acessado em 20.JA№2016, às 21:00.

South West Africa Cases (Ethiopia v. South Africa; Liberia v. South Africa). Preliminary Objetctions. Separate Opinion of Judge Bustamante. Judgment of 21 December 1962, disponível em http://www.icj-cij.org/files/case-related/47/047-19621221-JUD-01-02-ENopdf, acessado em 20.JANo2016, às 21:05.

South West Africa Cases (Ethiopia v. South Africa; Liberia v. South Africa). Preliminary Objetctions. Dissenting Opinion of President Winiarski. Judgment of 21 December 1962, disponível em http://www.icj-cij.org/files/case-related/47/047-19621221-JUD-01-05-ENopdf, acessado em 20.JANo2016, às 21:10. 
South West Africa Cases (Ethiopia v. South Africa; Liberia v. South Africa). Second Fase. Judgment on 18 JULY 1966, disponível em http://www.icj-cij.org/files/case-related/47/04719660718-JUD-01-00-ENopdf, acessado em 20.JANo2016, às 21:40.

Case concerning the Barcelona Traction, Light and Power Company, Limited (Belgium v. Spain). Second Fase. Judgment of 5 February 1970, acessado em http://www.icjcij.org/files/case-related/50/050-19700205-JUD-01-00-ENopdf, acessado em 20.FEV.2012, às 11:00.

Reservations to the Convention on the Prevention and Punishment of the Crime of Genocide. Advisory Opinion of May 28 1951, disponível em http://www.icjcij.org/docket/files/12/4283.pdf, acessado em 31.JUL.2007, às 14:32.

Arrest Warrant of 11 April 2000 (Democratic Republic of the Congo v. Belgium), disponível em http://www.icj-cij.org/docket/files/121/7081.pdf,acessado em 25.JUL.2012, às 10:00.

Questions Relating to the Obligation to Prosecute or Extradite (Belgium vs. Senegal), 20 July 2012. Disponível em http://www.icj-cij.org/docket/files/144/17064.pdf, acessado em 30.DEZ.2013, às 18:30.

Questions Relating to the Obligation to Prosecute or Extradite (Belgium vs. Senegal), Separate Opinion of Judge Cançado Trindade, 20 July 2012. Disponível em http://www.icjcij.org/docket/files/144/17072.pdf, acessado em 30.DEZ.2013, às 18:35.

Trabalho enviado em 30 de agosto de 2017.

Aceito em 12 de dezembro de 2017. 